\title{
CC Chemokines in a Tumor: A Review of Pro-Cancer and Anti-Cancer Properties of the Ligands of Receptors CCR1, CCR2, CCR3, and CCR4
}

\author{
Jan Korbecki ${ }^{1}{ }^{\mathbb{D}}$, Klaudyna Kojder ${ }^{2}$, Donata Simińska ${ }^{1} \mathbb{0}$, Romuald Bohatyrewicz ${ }^{2}$, \\ Izabela Gutowska ${ }^{3}\left[\right.$, Dariusz Chlubek ${ }^{1}(\mathbb{D})$ and Irena Baranowska-Bosiacka ${ }^{1, *}$ (i) \\ 1 Department of Biochemistry and Medical Chemistry, Pomeranian Medical University in Szczecin, \\ Powstańców Wielkopolskich 72, 70-111 Szczecin, Poland; jan.korbecki@onet.eu (J.K.); \\ d.siminska391@gmail.com (D.S.); dchlubek@pum.edu.pl (D.C.) \\ 2 Department of Anaesthesiology and Intensive Care, Pomeranian Medical University in Szczecin, \\ Unii Lubelskiej 1, 71-281 Szczecin, Poland; klaudynakojder@gmail.com (K.K.); \\ Romuald.bohatyrewicz@pum.edu.pl (R.B.) \\ 3 Department of Medical Chemistry, Pomeranian Medical University in Szczecin, Powstańców Wlkp. 72, \\ 70-111 Szczecin, Poland; izagut@poczta.onet.pl \\ * Correspondence: ika@pum.edu.pl
}

Received: 18 October 2020; Accepted: 8 November 2020; Published: 9 November 2020

\begin{abstract}
CC chemokines, a subfamily of 27 chemotactic cytokines, are a component of intercellular communication, which is crucial for the functioning of the tumor microenvironment. Although many individual chemokines have been well researched, there has been no comprehensive review presenting the role of all known human CC chemokines in the hallmarks of cancer, and this paper aims at filling this gap. The first part of this review discusses the importance of CCL1, CCL3, CCL4, CCL5, CCL18, CCL19, CCL20, CCL21, CCL25, CCL27, and CCL28 in cancer. Here, we discuss the significance of CCL2 (MCP-1), CCL7, CCL8, CCL11, CCL13, CCL14, CCL15, CCL16, CCL17, CCL22, CCL23, CCL24, and CCL26. The presentation of each chemokine includes its physiological function and then the role in tumor, including proliferation, drug resistance, migration, invasion, and organ-specific metastasis of tumor cells, as well as the effects on angiogenesis and lymphangiogenesis. We also discuss the effects of each CC chemokine on the recruitment of cancer-associated cells to the tumor niche (eosinophils, myeloid-derived suppressor cells (MDSC), tumor-associated macrophages (TAM), tumor-associated neutrophils (TAN), regulatory $\mathrm{T}$ cells $\left(\mathrm{T}_{\mathrm{reg}}\right)$ ). On the other hand, we also present the anti-cancer properties of CC chemokines, consisting in the recruitment of tumor-infiltrating lymphocytes (TIL).
\end{abstract}

Keywords: chemokine; CC chemokine; cancer; tumor; organ-specific metastasis; angiogenesis; lymphangiogenesis; tumor microenvironment; anti-cancer therapy; $\mathrm{MCP}-1$

\section{Introduction}

A high percentage of deaths in cancer treatment is partly due to inadequate treatment methods as a result of our incomplete understanding of cancer mechanisms. However, cancer models and treatment methods are improving and increasing their efficacy. Over the last 20 years, the perception of cancer cells in tumors has changed significantly [1,2]. Previously, research focused on the inside of a cancer cell, but, nowadays, more attention is paid to the tumor niche and tumor microenvironment, with a special focus on non-cancer cells and intercellular communication [3-5]. It is now known that tumor growth, and, thus, the progression of cancer, requires communication between cancer and non-cancer cells, involving chemokines among other things. 
Chemokines are a group of almost 50 chemoattractant cytokines and are divided into sub-families according to the domain found at the N-terminus [6,7]. One such sub-family are twenty-seven CC chemokines with an N-terminal CC domain, four of which (chemokine (C-C motif) ligand 6 (CCL6), CCL9/CCL10, and CCL12) are murine chemokines [6,7]. Although CC chemokines are presented using 28 symbols (CCL1 to CCL28), their actual number is 27, as chemokines CCL9 and CCL10 are actually the same chemokine. CC chemokines are ligands for ten classical receptors and serve as an important component of the tumor microenvironment and of cell relationships in the tumor niche, evidenced by their receptors association with the prognosis of patients with a particular type of tumor (Tables 1 and 2 based on "The Human Protein Atlas" (https://www.proteinatlas.org/) [8,9]. There are no single CC chemokines that give the same prognosis in all types of tumors, which is due to the differences between cancers and the fact that any given chemokine has both pro-cancer and anti-cancer properties. A chemokine may cause tumor infiltration of the tumor by tumor-infiltrating lymphocytes (TIL), the cells that destroy cancer cells $[10,11]$, whilst also recruiting tumor-associated cells that cooperate with cancer cells in tumor development $[12,13]$.

Table 1. Influence of increased expression of individual CC chemokines discussed in this review on the prognosis of patients with various cancers according to "The Human Protein Atlas" (https: //www.proteinatlas.org/) [8,9].

\begin{tabular}{|c|c|c|c|c|c|c|c|c|c|c|c|c|c|}
\hline $\begin{array}{l}\text { Type of } \\
\text { Cancer }\end{array}$ & CCL2 & CCL7 & CCL8 & CCL11 & CCL13 & $\begin{array}{r}\text { Ch } \\
\text { CCL14 }\end{array}$ & $\begin{array}{r}\text { emokin } \\
\text { CCL15 }\end{array}$ & CCL16 & CCL17 & CCL22 & CCL23 & CCL24 & CCL26 \\
\hline Glioma & $\downarrow$ & $\downarrow$ & $\begin{array}{l}\downarrow p= \\
0.095\end{array}$ & N/A & $\begin{array}{l}\downarrow p= \\
0.054\end{array}$ & - & N/A & N/A & $\uparrow$ & - & $\downarrow$ & $\downarrow$ & - \\
\hline $\begin{array}{l}\text { Thyroid } \\
\text { cancer }\end{array}$ & - & - & $\begin{array}{l}\uparrow p= \\
0.057\end{array}$ & - & - & - & $\uparrow$ & - & $\downarrow$ & $\downarrow$ & $\downarrow$ & - & - \\
\hline Lung cancer & $\begin{array}{l}\downarrow p= \\
0.075\end{array}$ & $\downarrow$ & - & $\begin{array}{l}\downarrow p= \\
0.081\end{array}$ & $\begin{array}{l}\uparrow p= \\
0.085\end{array}$ & - & - & - & $\uparrow$ & $\begin{array}{l}\uparrow p= \\
0.089\end{array}$ & - & - & $\begin{array}{l}\downarrow p= \\
0.062\end{array}$ \\
\hline $\begin{array}{c}\text { Colorectal } \\
\text { cancer }\end{array}$ & $\downarrow$ & $\begin{array}{l}\downarrow p= \\
0.085\end{array}$ & $\downarrow$ & $\uparrow$ & $\uparrow$ & $\uparrow$ & $\uparrow$ & - & $\begin{array}{l}\uparrow p= \\
0.058\end{array}$ & $\uparrow$ & $\begin{array}{l}\downarrow p= \\
0.10\end{array}$ & $\uparrow$ & - \\
\hline $\begin{array}{l}\text { Head and } \\
\text { neck cancer }\end{array}$ & $\begin{array}{l}\downarrow p= \\
0.086\end{array}$ & - & $\uparrow$ & $\begin{array}{l}\uparrow p= \\
0.058\end{array}$ & - & $\uparrow$ & N/A & - & $\uparrow$ & $\uparrow$ & - & $\begin{array}{l}\uparrow p= \\
0.056\end{array}$ & $\downarrow$ \\
\hline $\begin{array}{c}\text { Stomach } \\
\text { cancer }\end{array}$ & - & - & - & $\downarrow$ & - & $\downarrow$ & - & $\downarrow$ & - & $\begin{array}{l}\uparrow p= \\
0.077\end{array}$ & - & $\uparrow$ & $\uparrow$ \\
\hline Liver cancer & $\uparrow$ & N/A & - & - & $\begin{array}{l}\downarrow p= \\
0.076\end{array}$ & $\uparrow$ & $\begin{array}{l}\downarrow p= \\
0.089\end{array}$ & $\uparrow$ & - & - & $\uparrow$ & - & $\downarrow$ \\
\hline $\begin{array}{c}\text { Pancreatic } \\
\text { cancer }\end{array}$ & - & $\downarrow$ & - & $\downarrow$ & $\downarrow$ & $\uparrow$ & - & $\uparrow$ & - & $\uparrow$ & $\begin{array}{l}\uparrow p= \\
0.071\end{array}$ & - & $\begin{array}{l}\uparrow p= \\
0.079\end{array}$ \\
\hline $\begin{array}{l}\text { Renal } \\
\text { cancer }\end{array}$ & $\downarrow$ & $\downarrow$ & $\downarrow$ & $\downarrow$ & $\downarrow$ & $\downarrow$ & $\downarrow$ & $\downarrow$ & $\begin{array}{l}\downarrow p= \\
0.060\end{array}$ & $\uparrow$ & $\downarrow$ & - & $\downarrow$ \\
\hline $\begin{array}{c}\text { Urothelial } \\
\text { cancer }\end{array}$ & $\downarrow$ & $\downarrow$ & $\downarrow$ & $\downarrow$ & $\uparrow$ & - & $\uparrow$ & $\uparrow$ & $\uparrow$ & $\uparrow$ & - & $\downarrow$ & $\downarrow$ \\
\hline $\begin{array}{c}\text { Prostate } \\
\text { cancer }\end{array}$ & - & $\begin{array}{c}\uparrow p= \\
0.070\end{array}$ & - & - & $\begin{array}{l}\downarrow p= \\
0.060\end{array}$ & $\uparrow$ & $\uparrow$ & - & $\downarrow$ & - & $\begin{array}{c}\uparrow p= \\
0.069\end{array}$ & - & - \\
\hline $\begin{array}{c}\text { Testicular } \\
\text { cancer }\end{array}$ & $\downarrow$ & $\begin{array}{l}\downarrow p= \\
0.087\end{array}$ & $\downarrow$ & $\downarrow$ & - & - & - & - & $\downarrow$ & $\downarrow$ & - & - & - \\
\hline $\begin{array}{l}\text { Breast } \\
\text { cancer }\end{array}$ & $\begin{array}{l}\uparrow p= \\
0.064\end{array}$ & $\begin{array}{l}\uparrow p= \\
0.077\end{array}$ & $\begin{array}{l}\downarrow p= \\
0.075\end{array}$ & $\uparrow$ & $\uparrow$ & $\uparrow$ & - & - & $\uparrow$ & $\uparrow$ & $\uparrow$ & $\uparrow$ & - \\
\hline $\begin{array}{c}\text { Cervical } \\
\text { cancer }\end{array}$ & $\downarrow$ & $\downarrow$ & - & - & $\uparrow$ & $\begin{array}{l}\uparrow p= \\
0.058\end{array}$ & - & - & $\uparrow$ & $\uparrow$ & $\uparrow$ & - & - \\
\hline $\begin{array}{c}\text { Endometrial } \\
\text { cancer }\end{array}$ & $\begin{array}{l}\uparrow p= \\
0.056\end{array}$ & $\downarrow$ & $\downarrow$ & $\begin{array}{l}\downarrow p= \\
0.082\end{array}$ & $\uparrow$ & $\downarrow$ & - & $\downarrow$ & $\uparrow$ & $\uparrow$ & $\begin{array}{l}\downarrow p= \\
0.095\end{array}$ & $\uparrow$ & - \\
\hline $\begin{array}{c}\text { Ovarian } \\
\text { cancer }\end{array}$ & - & $\uparrow$ & $\uparrow$ & - & $\uparrow$ & $\begin{array}{l}\downarrow p= \\
0.081\end{array}$ & N/A & - & $\uparrow$ & $\uparrow$ & $\uparrow$ & - & $\begin{array}{l}\begin{array}{l}\uparrow p= \\
0.087\end{array} \\
\end{array}$ \\
\hline Melanoma & - & - & - & - & - & - & - & - & $\begin{array}{l}\uparrow p= \\
0.064\end{array}$ & - & $\begin{array}{l}\uparrow p= \\
0.065\end{array}$ & $\downarrow$ & - \\
\hline
\end{tabular}

$\uparrow$ blue background-better prognosis with higher expression of a given chemokine in a tumor; $\downarrow$ red background-worse prognosis with higher expression of a given chemokine in a tumor; - means no correlation with higher expression of a given chemokine in a tumor. 
Table 2. Effects of increased expression of individual CC chemokine receptors discussed in this review on the prognosis of patients with various cancers according to "The Human Protein Atlas" (https://www.proteinatlas.org/) [8,9].

\begin{tabular}{|c|c|c|c|c|}
\hline \multirow{2}{*}{ Type of Cancer } & \multicolumn{4}{|c|}{ Receptor } \\
\hline & CCR1 & CCR2 & CCR3 & CCR4 \\
\hline Glioma & $\downarrow p=0.095$ & $\downarrow$ & - & - \\
\hline Thyroid cancer & - & $\uparrow$ & - & - \\
\hline Lung cancer & $\downarrow p=0.088$ & $\uparrow$ & $\downarrow$ & $\uparrow$ \\
\hline Colorectal cancer & - & $\uparrow$ & - & $\uparrow$ \\
\hline Head and neck cancer & $\uparrow p=0.067$ & $\uparrow$ & $\downarrow$ & $\uparrow$ \\
\hline Stomach cancer & - & - & $\downarrow$ & - \\
\hline Liver cancer & - & $\uparrow p=0.081$ & $\downarrow$ & - \\
\hline Pancreatic cancer & - & - & $\downarrow$ & - \\
\hline Renal cancer & $\downarrow$ & $\downarrow$ & $\downarrow$ & $\downarrow$ \\
\hline Urothelial cancer & - & - & $\downarrow p=0.098$ & - \\
\hline Prostate cancer & - & - & $\uparrow$ & - \\
\hline Testicular cancer & $\downarrow$ & $\downarrow$ & $\downarrow$ & $\downarrow$ \\
\hline Breast cancer & - & $\uparrow$ & $\downarrow$ & $\uparrow$ \\
\hline Cervical cancer & - & $\uparrow$ & $\downarrow$ & $\uparrow$ \\
\hline Endometrial cancer & - & $\uparrow$ & $\downarrow$ & $\uparrow$ \\
\hline Ovarian cancer & $\uparrow$ & $\uparrow$ & $\uparrow$ & $\uparrow$ \\
\hline Melanoma & $\uparrow$ & $\uparrow p=0.063$ & $\downarrow$ & $\uparrow$ \\
\hline
\end{tabular}

As there is no comprehensive and up-to-date compendium that discusses the role of all human CC chemokines in cancer, the aim of this review was to collect all information about the involvement of each human CC chemokine in the hallmarks of cancer. Due to the large amount of data, we decided to divide the paper into two parts. In the first part we discuss CC chemokine receptors CCR1, CCR2, CCR3, and CCR4 together with their main ligands (CCL2, CCL7, CCL8, CCL11, CCL13, CCL14, CCL15, CCL16, CCL17, CCL22, CCL23, CCL24, and CCL26) (Tables 3 and 4) [6,7]. In the second part, we present receptors CCR5, CCR6, CCR7, CCR8, CCR9 and CCR10 and their ligands (CCL1, CCL3, CCL4, CCL5, CCL18, CCL19, CCL20, CCL21, CCL25, CCL27, and CCL28) [14]. The described chemokines are presented according to the receptor that they activate. However, many CC chemokines are ligands for more than one receptor, and for this reason, we also discuss them according to their shared properties. In order to better understand the role of individual CC chemokines in cancer, special attention has been paid to their physiological functions.

Table 3. CC chemokines discussed in this part of the article, including cells recruited to the tumor niche.

\begin{tabular}{ccccc}
\hline Name & Receptor & $\begin{array}{c}\text { Effect on the Recruitment } \\
\text { of Non-Cancer Cells } \\
\text { into the Tumor }\end{array}$ & $\begin{array}{c}\text { Induction of } \\
\text { Angiogenesis or } \\
\text { Lymphangiogenesis }\end{array}$ & $\begin{array}{c}\text { Organ-Specific } \\
\text { Metastasis }\end{array}$ \\
\hline CCL2 & $\begin{array}{c}\text { CCR1 (low-affinity } \\
\text { binding), CCR2, CCR3 } \\
\text { antagonist), CCR4, CCR5 }\end{array}$ & $\begin{array}{c}\text { TIL, MDSC, MSC, TAM, } \\
\mathrm{T}_{\text {reg, }} \text { Th17, neural } \\
\text { progenitor cells, microglia, } \\
\text { hepatic stellate cells }\end{array}$ & Angiogenesis & $\begin{array}{c}\text { Bone, perineural } \\
\text { invasion }\end{array}$ \\
\hline CCL7 & $\begin{array}{c}\text { CCR1, CCR2, CCR3, CCR5 } \\
\text { (antagonist) }\end{array}$ & TIL, TAM & \\
\hline CCL8 & CCR1, CCR2, CCR3, CCR5 & TAM, $\mathrm{T}_{\text {reg }}$ & \\
\hline CCL11 & $\begin{array}{c}\text { CCR2 (antagonist), CCR3, } \\
\text { CCR5 }\end{array}$ & Eosinophils & \\
\hline CCL13 & CCR2, CCR3, CCR5 & & \\
\hline
\end{tabular}


Table 3. Cont.

\begin{tabular}{|c|c|c|c|c|}
\hline Name & Receptor & $\begin{array}{l}\text { Effect on the Recruitment } \\
\text { of Non-Cancer Cells } \\
\text { into the Tumor }\end{array}$ & $\begin{array}{l}\text { Induction of } \\
\text { Angiogenesis or } \\
\text { Lymphangiogenesis }\end{array}$ & $\begin{array}{l}\text { Organ-Specific } \\
\text { Metastasis }\end{array}$ \\
\hline CCL14 & $\begin{array}{c}\text { CCR1, CCR3 } \\
\text { (low-affinity binding), } \\
\text { CCR5 }\end{array}$ & TAM & Angiogenesis & \\
\hline CCL15 & CCR1, CCR3 & $\begin{array}{c}\text { MDSC, MSC, TAM, TAN, } \\
\text { osteoclast precursors, } \\
\text { osteoclasts }\end{array}$ & Angiogenesis & \\
\hline CCL16 & $\begin{array}{l}\text { CCR1, CCR2, CCR5, CCR8, } \\
\text { histamine H4 receptor }\end{array}$ & & Angiogenesis & \\
\hline CCL17 & CCR4 & $\begin{array}{l}\text { TIL, } \mathrm{T}_{\text {reg, }} \text { Th17, } \\
\text { eosinophils }\end{array}$ & & \\
\hline CCL22 & CCR4 & $\begin{array}{l}\text { TIL, } \mathrm{T}_{\text {reg }}, \text { Th17, } \\
\text { eosinophils }\end{array}$ & & Bone \\
\hline CCL23 & CCR1 & & Angiogenesis & \\
\hline CCL24 & CCR2 (antagonist), CCR3, & Eosinophils & Angiogenesis & \\
\hline CCL26 & $\begin{array}{c}\text { CCR1 (antagonist), CCR2 } \\
\text { (antagonist), CCR3, CCR5 } \\
\text { (antagonist), CX3CR1 }\end{array}$ & Eosinophils, MDSC, TAM & Angiogenesis & \\
\hline
\end{tabular}

Table 4. Receptors of CC chemokines discussed in this part of the paper, with their ligands and functions in a tumor.

\begin{tabular}{|c|c|c|c|c|}
\hline Receptor & Ligand & $\begin{array}{l}\text { Influence on the } \\
\text { Recruitment of Cells } \\
\text { into the Tumor Niche }\end{array}$ & $\begin{array}{l}\text { Effects on Tumor } \\
\text { Vascularization }\end{array}$ & $\begin{array}{l}\text { Organ-Specific } \\
\text { Metastasis }\end{array}$ \\
\hline CCR1 & $\begin{array}{c}\text { CCL2, CCL3, CCL4, CCL5, } \\
\text { CCL7, CCL8, CCL14, } \\
\text { CCL15, CCL16, CCL23 }\end{array}$ & $\begin{array}{l}\text { MDSC, MSC, TAM, TAN, } \\
\text { osteoclast precursors, } \\
\text { osteoclasts }\end{array}$ & $\begin{array}{l}\text { Increase in VEGF } \\
\text { expression which } \\
\text { leads to } \\
\text { angiogenesis }\end{array}$ & Liver \\
\hline CCR2 & $\begin{array}{l}\text { CCL2, CCL7, CCL8, } \\
\text { CCL13, CCL16 }\end{array}$ & MDSC, MSC, TAM, $\mathrm{T}_{\mathrm{reg}}$ & $\begin{array}{l}\text { TAM-dependent } \\
\text { angiogenesis }\end{array}$ & $\begin{array}{l}\text { Bone, perineural } \\
\text { invasion }\end{array}$ \\
\hline CCR3 & $\begin{array}{c}\text { CCL5, CCL7, CCL8, } \\
\text { CCL11, CCL13, } \\
\text { CCL14, } \\
\text { CCL15, CCL24, CCL26, } \\
\text { CCL28 }\end{array}$ & Eosinophils, TAM & Angiogenesis & \\
\hline CCR4 & CCL2, CCL17, CCL22 & TIL, Th17, $\mathrm{T}_{\text {reg }}$ & & Lymph node, bone \\
\hline
\end{tabular}

\section{CCR1}

\subsection{CCL14}

CCL14 (also known as hemofiltrate CC chemokine (HCC)-1), occurs in high concentrations in plasma [15]. The expression of this chemokine has also been found in organs such as spleen, colon, small intestine, liver, muscle, and bone marrow but not in the brain and kidney [15]. CCL14 is a ligand of CCR1 [16,17], CCR5 [17,18], and a weak agonist of CCR3 [17]. For this reason, it serves as a chemotactic agent for monocytes but not for T lymphocytes, neutrophils, and eosinophils [15], although a later study showed that CCL14 may be a neutrophil chemoattractant [19]. 
CCL14 is secreted as an inactive proform. Following the cleavage of the 8-amino acid fragment by the urokinase-type plasminogen activator (uPA), plasmin or kallikrein-related peptidases, it is converted to an active form [20-23], which may be further processed by the cleavage of two amino acids by dipeptidyl peptidase IV (DPPIV)/CD26, which inactivates the active form of CCL14 [24]. The active form of CCL14 can also be broken down by atypical chemokine receptor 2 (ACKR2)/D6 [24]; however, the expression of this receptor decreases as the tumor develops [25-27].

The physiological function of CCL14 is poorly understood. It is important in the functioning of bone marrow by stimulating the proliferation of CD34 ${ }^{+}$human bone marrow cells [15]. CCL14 causes changes in extracellular matrix in the trophoblast, which induces trophoblast cell migration and embryo implantation [28].

CCL14 has anti- and pro-cancer properties. The expression of this chemokine is reduced in many solid tumors including in liver, breast, lung, and prostate cancer $[29,30]$. On the other hand, it is elevated in brain and esophageal cancer [30]. Since CCL14 is present in high concentrations in plasma and is activated by appropriate proteinases $[15,20,21]$, it can act locally at the site of proteinase activity, e.g., uPA and plasmin.

CCL14 reduces the activation of the Wnt/ $\beta$-catenin pathway in hepatocellular carcinoma cells, which inhibits their proliferation and causes their apoptosis [29]. CCL14 also has pro-cancer properties-it induces the migration of cancer cells, as shown by an experiment on breast cancer cells [31], and also causes angiogenesis [31]. It is also postulated that the CCL14 $\rightarrow$ CCR1 axis is crucial in liver metastasis $[15,32]$. In addition, CCL14 participates in the recruitment of monocytes into the tumor niche, especially to bone marrow, as shown on a multiple myeloma model [33]. The monocytes are then converted into tumor-associated macrophages (TAM) by the tumor microenvironment. Subsequently, CCL14 increases the proliferation of TAM, which increases the number of these cells in the tumor niche [33]. Although CCL14 can participate in the infiltration of the tumor by anti-cancer TIL [30], a study on hepatocellular carcinoma has shown a negative correlation between the concentration of CCL14 and such infiltration [30], and so the effect of CCL14 on the response of the immune system to cancer requires further study.

\subsection{CCL15}

CCL15 (also known as HCC-2, macrophage inflammatory protein (MIP)-18, MIP-5, leukotactin-1) activates two receptors: CCR1 [34-36] and CCR3 [34,35], with the N-terminally truncated form of this chemokine showing a strong affinity for CCR1 [22,37,38]. CCL15 is a chemotactic agent for monocytes, eosinophils, and neutrophils [35,36]. It has the greatest expression in the gut and liver [36] and so is crucial for maintaining immune balance in these organs.

CCL15 is a serum biomarker and independent predictor of survival in hepatocellular carcinoma [39,40]. The higher the concentration of CCL15, the worse the prognosis-an effect associated with the migration and invasion of these cells, induced by CCL15 via CCR1 [40]. In head and neck squamous cell carcinoma, activation of CCR1 by the described chemokine induces apoptosis resistance and drug resistance by activating nuclear factor $\mathrm{\kappa B}$ (NF- $\mathrm{KB})$ [41]. CCL15 is crucial for the metastasis of renal cell carcinoma. If the cancer cell stops in the bone, CCL15, produced by the cancer cell, acts chemotactically on osteoclast precursors and osteoclasts, probably via CCR1 and CCR3 [42]. In this case, CCL15 causes osteoclastogenesis, which is followed by bone remodeling around the tumor cell and the formation of a metastatic niche [43]. The CCL15 $\rightarrow$ CCR1 axis is also postulated to play an important role in liver metastasis [32,36].

CCL15 also acts on non-cancer cells in the tumor, for example causing angiogenesis mediated by CCR1 and CCR3 on vascular endothelial cells [44]. In addition, in hepatocellular carcinoma and colorectal cancer, CCL15 is responsible for recruiting TAM and myeloid-derived suppressor cells (MDSC) [45,46] and for recruiting mesenchymal stem cells (MSC) into the tumor niche [47]. Colorectal cancer models have shown that CCL15 causes tumor-associated neutrophils (TAN) recruitment to the tumor niche via CCR1 on these cells [48]. 


\subsection{CCL16}

Chemokine CCL16 (other names: HCC-4, liver expressed chemokine (LEC), liver-specific CC chemokine-1 (LCC-1)) is constitutively expressed in the liver and by hepatoma cells [6,49], as well as by monocytes treated with interleukin (IL)-10 [50]. High concentrations of CCL16 can be found in the blood [51]. It is a ligand for CCR1 [51-54], CCR2 [51], CCR5 [51] and CCR8 [52]. CCL16 is a ligand of the histamine $\mathrm{H} 4$ receptor and therefore may act on eosinophils [55].

Receptor CCR1 is important in liver metastasis [32] and so it can be postulated that CCL14 [15], CCL15 [36] and CCL16 [49], i.e., chemokines with a high expression in the liver and at the same time, ligands for CCR1, may cause liver metastasis. Another pro-cancer property of CCL16 is the induction of angiogenesis, related to the expression of its receptor CCR1 on vascular endothelial cells [53]. CCL16 also causes the migration of cancer cells if they exhibit CCR1 expression [54].

On the other hand, CCL16 enhances the anti-cancer effects of cytotoxic T and dendritic cells (DC) lymphocytes $[56,57]$ and some consider the possibility of using of this chemokine for enhancing the anticancer response in cancer immunotherapy [58-61].

\subsection{CCL23}

CCL23 (also known as CK $\beta 8$, MIP-3, and myeloid progenitor inhibitory factor-1 (MPIF-1)) is produced by eosinophils [62], monocyte-derived dendritic cells [63] and monocytes activated by interleukin (IL)-1 $\beta$ [64]. It serves as a chemoattractant for dendritic cells, resting $T$ lymphocytes and monocytes, but not in T cells and eosinophils [63-67]. CCL23 is a ligand for CCR1 [67,68], and the $\mathrm{N}$-terminally truncated form of this chemokine has a strong affinity for CCR1 $[37,38]$. Due to alternative splicing, CCL23 occurs in two forms, shorter CCL23 $\alpha / C K \beta 8$ and longer CCL23 $\beta / C K \beta 8-1[66,67]$. The shorter form activates CCR1 more strongly [66]. However, CCL23 $\beta$ can be cleaved at the C-terminus [69], which results in the release of SHAAGtide, a peptide which is a ligand for formyl peptide receptor-like 1 (FPRL1) - the activation of this receptor causes the migration of monocytes and neutrophils. CCL23 suppresses differentiation of myeloid progenitor cells [70]. For this reason, increased expression of CCL23 in acute myeloid leukemia cells leads to the suppression of hematopoiesis [71].

There are few studies indicating the involvement of CCL23 in cancer. However, it seems that this chemokine has both pro- and anti-cancer properties. It stimulates the proliferation of cells with CCR1 expression [72]. For this reason, it can be assumed that CCL23 increases the proliferation of cancer cells. CCL23 is secreted by macrophages in omentum and so the CCL23 $\rightarrow$ CCR1 axis is crucial for omentum metastasis in ovarian cancer [73]. CCL23 is also a chemotactic agent for osteoclast precursors via CCR1 on these cells [74] and so it may play some role in bone remodeling and the formation of a metastatic niche in bones. However, the most important pro-cancer function of CCL23 may be the induction of angiogenesis by activating CCR1 on vascular endothelial cells [75,76], a process associated with increased expression and secretion of matrix metalloproteinase (MMP)-2 from these cells. CCL23 also induces an increase in the expression of the kinase insert domain-containing receptor (KDR)/fms-like tyrosine kinase 1 (Flk-1) on vascular endothelial cells [77], which enhances the effect of vascular endothelial growth factor (VEGF) on these cells. However, there are no studies on the involvement of CCL23 in angiogenesis inside the tumor.

CCL23 can also influence cancer-associated cells. For example, this chemokine may contribute to the function of eosinophils in a tumor [62]. It is also a chemoattractant for various cells of the immune system and therefore may cause the recruitment of some cells into the tumor niche [64-68]. It is yet to be established whether it causes tumor infiltration by anti-cancer TIL or participates in the recruitment of cancer-related cells, in particular MDSC, TAM, TAN and regulatory T cells $\left(\mathrm{T}_{\text {reg }}\right)$.

\section{CCR2 and Its Ligands: CCL2, CCL7, CCL8, and CCL13}

CCL2 (also known as monocyte chemoattractant protein (MCP)-1) [78], CCL7 (also known as MCP-3) [79,80], CCL8 (also known as MCP-2) [81] and CCL13 (also known as MCP-4) [80,82,83] 
are ligands for CCR2. However, CCL2 can also activate CCR4 [84], CCR5 [85] and-at high concentrations-CCR1 [86]. CCL2 is also an antagonist of CCR3 [87]. CCL7 can also activate CCR1 $[79,88$ ] and CCR3 [89] and is an antagonist of CCR5 [85]. CCL8 can also activate CCR1 [81], CCR3 [89] and CCR5 [85,90,91]. CCL13 is also a ligand for CCR3 [82,83,89] and CCR5 [85]. CCL2, CCL7, and CCL8 are proteolytically spliced at the C-terminus, which is necessary for the acquisition of chemotactic properties by these chemokines [22]. However, cleavage at the N-terminus by MMPs makes them antagonists of their own receptors [22,92]. Another mechanism for reducing the activity of the described subgroup of chemokines is the chemokine decoy receptor ACKR2/D6 which reduces the level of this and many other CC chemokines [25-27]. However, the expression of this receptor in tumors is gradually reduced along with the progress of tumor growth.

One of the most important functions of the discussed subgroup of chemokines is the recruitment of monocytes to inflammatory reaction sites [93-96]. However, the discussed chemokines are involved in the recruitment of basophils, T cells, and NK (natural killer) cells [93,97]. In addition, CCL7 and CCL8 are chemoattractants for eosinophils [93]. Due to the activation of CCR3 by CCL13, this chemokine is important in the pathogenesis of allergic inflammation and asthma because it shows chemotactic activity against monocytes and eosinophils $[82,98,99]$. Due to the recruitment of monocytes, CCL2, CCL7, CCL8, and CCL13 are important in the pathogenesis of many diseases where an important role is played by monocytes and macrophages, in particular atherosclerosis, inflammatory bowel disease, and cancer.

The expression of chemokines from this subgroup increases in many cancers. Breast cancer is associated with increased CCL7 expression [100], while glioblastoma multiforme is accompanied by increased concentrations of CCL2 and CCL7 [101]. On the other hand, in some cancers, e.g., in ovarian adenocarcinoma, the expression of CCL2 decreases [102].

In a tumor, CCL2 is produced by cancer cells (Figure 1) [103-109]. The expression of this chemokine may be increased by factors such as growth factors [110], radiotherapy [107], cycling hypoxia [111] and anti-cancer drugs [112], or interactions with other cells, including cancer-associated fibroblasts (CAF) [113]. However, the expression of this chemokine in a tumor also occurs in MDSC [114], MSC [115], TAM [104,116-118], TAN [119], and CAF [120-122]. CCL7 and CCL8 are also expressed in CAF [123-125] and TAM [126]. The expression of CCL2, CCL7, and CCL8 in CAF is very important in cancer. Their expression is increased in CAF under the influence of interaction with a cancer cell, an important effect in the initial stages of metastatic niche formation and the functioning of a tumor $[123,124,127-130]$.

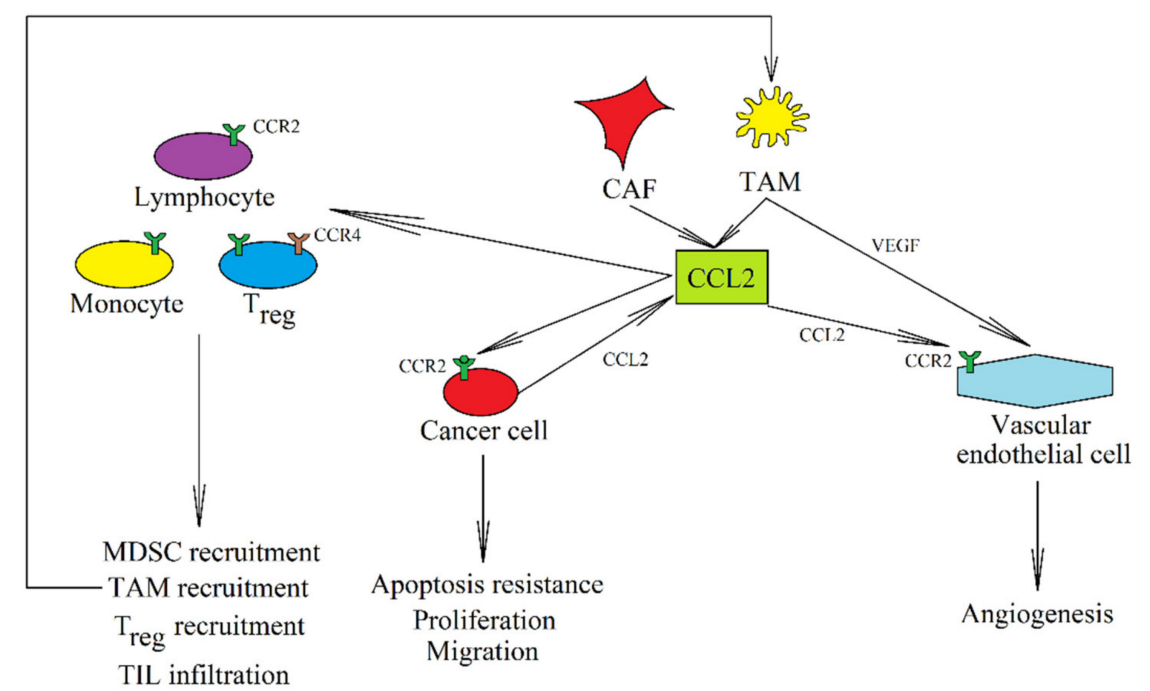

Figure 1. The role of CCL2 in caner. In a tumor, CCL2 is produced by tumor cells and by CAF and TAM. It activates its receptor, CCR2, on a tumor cell, which stimulates the proliferation of cancer cells and causes their migration and resistance to apoptosis. CCL2 also acts on non-cancer cells, e.g., activating CCR2 on vascular endothelial cells which results in angiogenesis. CCL2 causes the recruitment of MDSC, $\mathrm{TAM}$, and $\mathrm{T}_{\text {reg }}$ into the tumor niche but also induces the infiltration of the tumor by anti-cancer TIL. 
Increased expression of CCL2 in a tumor is associated with a worse prognosis for patients with solid tumors [131]. This is associated with the multiple pro-cancer properties of this chemokine. The most important function of CCL2 is the CCR2-mediated recruitment of TAM [12,13,103,132-135] and MDSC $[13,122]$ into the tumor niche. CCL2 is also one of the factors contributing to M2-type macrophage polarization [136]. It can also recruit one of the $T_{\text {reg }}$ subsets that shows CCR2 expression $[137,138]$. The recruitment of other $T_{\text {reg }}$ subsets by CCL2 may also depend on the activation of CCR4 by this chemokine [84]. CCL2 can also recruit T helper type 17 (Th17) [139] and MSC [140] into the tumor niche. In brain tumors, CCL2 participates in the recruitment of neural progenitor cells [141] and microglia [142]. In liver cancer, CCL2 additionally causes the recruitment of hepatic stellate cells [143]. TAM recruitment can also be induced by CCL7 [144] and CCL8 [145], while $\mathrm{T}_{\text {reg }}$ are recruited into the tumor niche by CCL8 [91] into the tumor niche.

CCL2 [10,11,146-148] and CCL7 [149,150] may also cause infiltration of the tumor by TIL, which has an anti-cancer effect. However, it seems that CCL2 in a tumor interferes with the function of anti-cancer T lymphocytes [151] and dendritic cells [152]. The discussed group of CC chemokines (CCL2, CCL7, CCL8, and CCL13) have numerous pro-cancer functions, which outweigh their anti-cancer properties. For example, the prognosis for patients is worse when the expression of CCL2 in the tumor is elevated [131].

CCL2 and CCL8 increase cancer cell proliferation [108,153,154]. CCL2 and CCL8 also cause enhanced tumor cell stemness and cancer stem cells self-renewal [127,155]. CCL2 also increases apoptosis resistance and drug resistance by activating the phosphatidylinositol-4,5-bisphosphate 3-kinase $(\mathrm{PI} 3 \mathrm{~K}) \rightarrow$ Akt/protein kinase $\mathrm{B}(\mathrm{PKB}) \rightarrow$ mammalian target of rapamycin (mTOR) pathway [156-158]. This is of great importance as the expression of this chemokine can be increased by radiotherapy [107] and anti-cancer drugs [112]. For this reason, it is postulated to administer additional drugs to disrupt the function of CCL2 during cancer therapy.

CCL2 $[86,156,159,160]$, CCL7 $[123,161]$, and CCL8 $[124,125,159]$ cause cancer cell migration. CCL2 also causes epithelial-to-mesenchymal transition (EMT) by activating the extracellular signal-regulated kinase (ERK) mitogen-activated protein kinase (MAPK) $\rightarrow$ glycogen synthase kinase-3 $\beta$ $($ GSK-3 3$) \rightarrow$ Snail and PI3K $\rightarrow$ Akt/PKB pathways [162,163]. CCL7 [164] and CCL8 [155,165] also cause EMT. CCL2 is crucial for the subsequent stages of metastasis. After EMT, a cancer cell increases the expression of CCL2 [166]. This allows it to effectively recruit macrophages, which participate in the early stage of the development of a metastatic niche [134,167]. However, at this stage CCL2 can also recruit neutrophils, which have a destructive effect on cancer cells [168].

In further stages of metastasis, CCL2 participates in the formation of a metastatic niche. As CCL2 is secreted by bone marrow endothelial cells [169], it causes the diapedesis of cancer cells into the bone tissue. Bone metastasis in prostate cancer is closely related to osteoblasts because prostate cancer cells secrete parathyroid hormone related proteins (PTHrP) that cause an increase in CCL2 expression in osteoblasts $[170,171]$. CCL2 can also be directly produced by other cancer cells $[106,172,173]$. Then the described chemokine causes the differentiation of osteoclasts, which are involved in bone remodeling and the formation of a metastatic niche [174]. CCL2 is also important in the perineural invasion of cervical cancer and prostate cancer $[175,176]$, due to the expression of CCL2 in the nervous tissue. In particular, this chemokine is secreted by Schwann cells and supports the formation of metastasis by acting on cancer cells.

CCL2 can also directly cause angiogenesis, by acting on vascular endothelial cells on which it is expressed CCR2 [104,177]. However, some studies have shown that vascular endothelial cells in tumors do not express CCR2 [103,133], and so it seems that CCL2 may indirectly cause angiogenesis by recruiting TAM and increasing VEGF-A expression in these cells [132,133,135,178,179]. Angiogenesis may also be indirectly caused by the CCL2-mediated increase in VEGF expression in a cancer cell $[108,156]$. In comparison, there are no published studies showing the direct effects of CCL2, CCL7, CCL8, and CCL13 on lymphangiogenesis. It is possible that these CC chemokines have an indirect impact on this process via tumor-recruited TAM [180]. 
There are no studies showing the importance of CCL13 in cancer. However, it has been proven that this chemokine may increase apoptosis resistance [181]. In a tumor, it might cause cancer cells to become drug resistant. As this chemokine activates CCR2 and CCR3, it should have the same properties as other ligands for these receptors: CCL2 and eotaxins, but this needs to be confirmed by further research.

\section{CCR3 and Eotaxins: CCL11 (Eotaxin-1), CCL24 (Eotaxin-2), and CCL26 (Eotaxin-3)}

Eotaxins are three CC chemokines: CCL11 (eotaxin-1), CCL24 (eotaxin-2, also known as CK6 and MPIF-2) and CCL26 (eotaxin-3). Their most important receptor is CCR3 [182-185]. CCL11 is also a ligand of CCR5 [85,186] but also an antagonist of CCR2 [186]. CCL24 is an antagonist of CCR2 [87]. CCL26 is a ligand of CX3C motif chemokine receptor 1 (CX3CR1) $[187,188]$ but also an antagonist of CCR1, CCR2, and CCR5 [189,190]. Eotaxins are the main chemotactic factors for eosinophils and to a lesser extent for basophils $[7,183,191]$. For this reason, eotaxins play a significant role in the pathophysiology of allergic reactions [184,192-194].

An elevated expression of eotaxins also occurs in tumors such as breast cancer [100], colorectal cancer [195] and oral squamous cell carcinomas [196], where it is associated with the recruitment of eosinophils into the tumor niche (Figure 2). However, the role of eosinophils in tumor is not clear [197-199], as they show both pro- and anti-cancer characteristics depending on the type of tumor. In addition to the recruitment of eosinophils, CCL26 has also been shown to cause TAM recruitment depending on CCR3 [200] and CX3CR1-dependent recruitment of MDSC into the tumor niche [188].

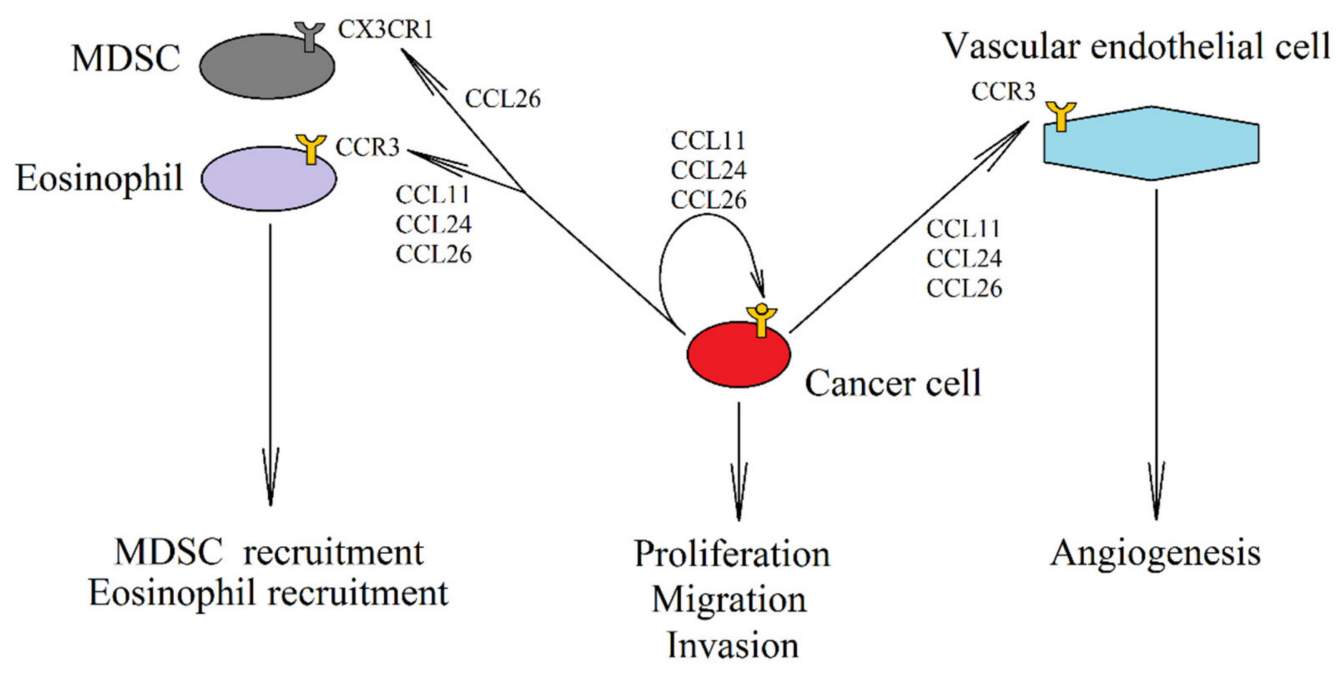

Figure 2. The role of eotaxins in cancer. In a neoplastic cell there is an expression of CCL11 (eotaxin-1), CCL24 (eotaxin-2) and CCL26 (eotaxin-3). This increases the autocrine proliferation and causes the migration of cancer cells with CCR3 expression. Eotaxins also activate the CCR3 receptor on endothelial cells, which results in angiogenesis. Another effect of an increased expression of eotaxins in the tumor is the recruitment of cells into the tumor niche, in particular eosinophils, by all three eotaxins through the CCR3 receptor. MDSC are recruited into the tumor by CCL26 via CX3CR1.

Eotaxins do not only influence the composition of cells in the tumor niche. Increased expression of CCR3 has been reported in tumors such as renal cell carcinoma [201] or glioma [101]. Activation of this receptor on a cancer cell increases proliferation and migration [201-203]. CCL11 causes cancer cell apoptosis resistance by activating ERK MAPK [204]. Eotaxins also increase tumor vascularization. Due to the fact that CCR3 is expressed on vascular endothelial cells, eotaxins-especially CCL11—cause angiogenesis $[205,206]$. CCL11 may also indirectly affect angiogenesis, as the activation of the CCR3 receptor by CCL11 increases VEGF expression in the hepatocellular carcinoma cells and thus promotes 
angiogenesis [207]. On the other hand, angiogenesis is inhibited by eosinophils recruited by eotaxins, which leads to the necrosis of some areas in a tumor [199].

\section{CCR4 and Its Ligands CCL17 and CCL22}

CCL17 (also known as thymus and activation regulated chemokine (TARC)) [208] and CCL22 (also known as macrophage-derived chemokine (MDC)) [209] are the ligands for CCR4. These chemokines are the chemotactic factor for Th 2 and $\mathrm{T}_{\text {reg }}$ due to the expression of the CCR4 on these cells [210] and for this reason they are important in the pathogenesis of asthma and allergy. CCL17 and CCL22 are also crucial in the homing of lymphocytes to the skin [210]. They exert an anti-cancer effect by causing the infiltration of TIL into the tumor [211,212], a process dependent on CCR4 on these cells.

On the other hand, the expression of CCL17 and CCL22 is elevated in a breast cancer tumor [100], CCL22 expression is increased in colorectal adenocarcinomas [213], while CCL17 expression is increased in glioblastoma multiforme [101]. CCL17 and CCL22 are both produced by cancer cells in a tumor (Figure 3) $[214,215]$ and by TAM [118,214,216-219]. CCL17 is also produced in TAN [119,220] and CAF [221].

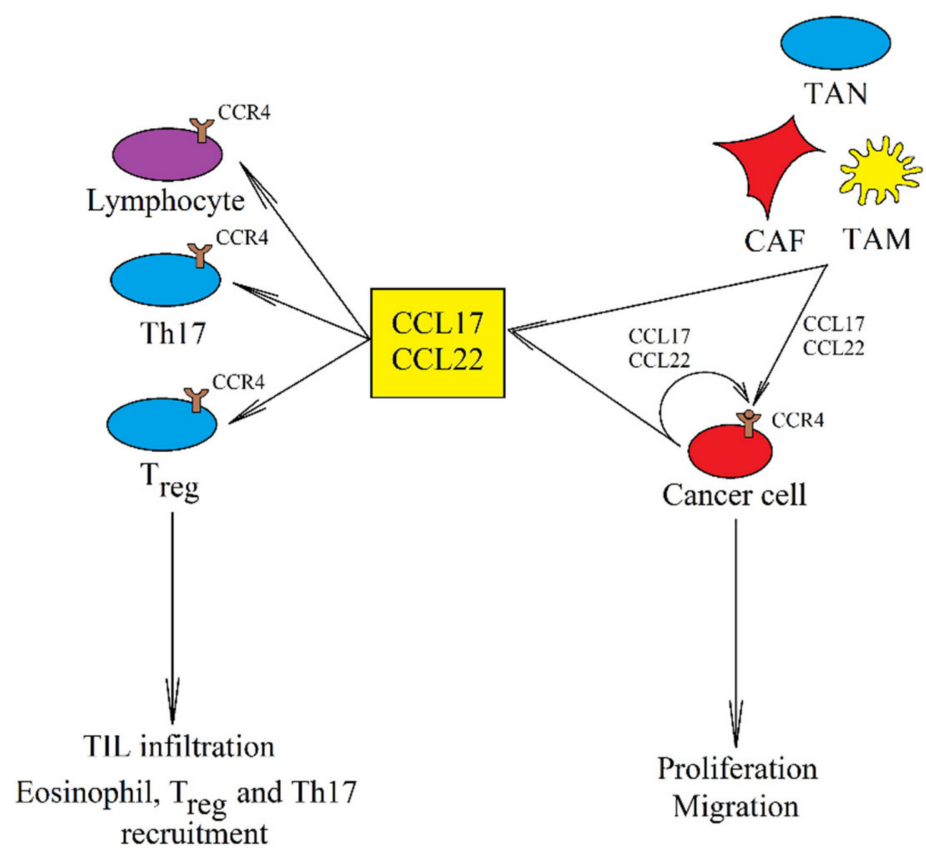

Figure 3. The role of CCL17 and CCL22 in cancer. These two chemokines are produced by cancer cells, CAF, TAM, and TAN. They increase the proliferation of cancer cells and their migration and invasion. They also cause the recruitment of $\mathrm{T}_{\text {reg }}$ and Th17. However, they can also cause infiltration of the tumor by TIL, which has an anti-cancer effect.

CCL17 and CCL22 are responsible for CCR4-dependent recruitment of $\mathrm{T}_{\text {reg }}$ into the tumor niche, which enhances cancer immune evasion [220,222-225]. They can also recruit eosinophils [226] and Th17 [227] into the tumor niche. At the same time, these chemokines may also cause infiltration of the tumor by anti-cancer TIL [211,212]. Due to the recruitment of cancer-related cells in the squamous cell carcinoma of the tongue into the tumor niche, increased expression of CCL22 is associated with a poorer prognosis [219]. The same applies to the increased expression of CCL17 in breast cancer [228]. In contrast, an increased expression of CCL22 in the tumor improves prognosis in lung cancer patients [229] and elevated CCL17 blood levels improve prognosis in melanoma patients [230].

Although are no studies showing the direct effects of CCL17 and CCL22 on angiogenesis, $\mathrm{T}_{\text {reg }}$ recruited by CCL17 and CCL22 do have pro-angiogenic properties via the secretion of VEGF [231]. 
CCL17 and CCL22 promote stemness of cancer cells with CCR4 expression [218], drug resistance [232], stimulate the proliferation of cancer cells [233], and cause cancer cell migration and EMT, as shown on many types of cancers [214,218,234]. Cancer cell migration is associated with metastasis. CCR4 expression has been linked to lymph node metastasis [214] and omental milky spots metastasis [235]. The CCL22 $\rightarrow$ CCR4 axis also participates in bone metastasis due to the high expression of CCL22 in bones [236]. Brain [237] and lung [238] metastasis have also been associated with CCR4 expression. However, in these organs the expression of CCR4 ligands is low [239] and for this reason, the described axis may participate in metastasis only at the stage of induction where there is cell migration from the parent tumor.

\section{CC Chemokines in Therapy}

Many of the aforementioned CC chemokines simultaneously cause infiltration of a tumor by anti-cancer TIL while also recruiting cells which support the growth of the tumor. As the action of these chemokines depends on the tumor microenvironment [240], this a key area that should be studied in order to develop more effective therapeutic approaches. Importantly, a balance between pro- and anti-cancer mechanisms in the tumor microenvironment differs depending on the type of cancer, which means that an increased expression of a given CC chemokine may either improve or worsen a prognosis, as shown in Table 1 above [8,9]. Despite this, cancer therapies which target CC chemokines hold a lot of promise, as shown by in vivo and clinical trials, especially in combination with immunotherapy [241-244].

To date, few studies have centered on the significance of the ligands of CCR1 as therapeutic targets in cancer therapies. The most researched ligand has been CCL16 whose increased expression has shown an anti-cancer effect in mouse breast cancer [60,245], and colon carcinoma [245], and prostate cancer [246] due to an increase in the infiltration of the tumor by CD4+ T cells, CD8+ T cells, and DC. This effect may be enhanced by the use of factors that intensify the immune response, such as CpG (Toll-like receptor 9 ligand) and anti-IL-10 receptor antibody [245,246]. Another therapeutic approach includes the use of a CCR1 antagonist, for example BL5923, which reduces the recruitment of immature myeloid cells into the tumor and inhibits liver metastasis in mice with colon cancer [247].

CCL2 and CLL7 have also been well researched as therapeutic targets in cancer therapy due to their significant function in tumors. An increased expression of these ligands is often associated with a worse prognosis in various cancers $[8,9,131]$. Therefore, the use of CCL2 siRNA, CCR2 siRNA, CCL2-neutralizing antibodies, CCL2 inhibitors or CCR2 antagonists has given promising results in the therapy of cancers such as breast cancer [248,249], glioma [250-252], and hepatocellular cancer [253] in laboratory animals inoculated with cancer cells. CCR2-targeted drugs have also been tested, for example, CCR2-targeted apoptotic peptide was used in the therapy of melanoma in laboratory animals [254]. Anti-cancer properties have also been shown in the clinical trials of carlumab (CNTO888), a monoclonal antibody against CCL2, in patients with solid tumors [255].

Another therapeutic approach is to block the CCL2 $\rightarrow$ CCR2 axis in chemotherapy or radiotherapy [256]. Chemotherapy induces an increase in CCL2 expression which results in apoptosis resistance [257]. As CCL2 causes a resistance to drugs such as cabazitaxel [157], docetaxel [257], and tamoxifen [158], blocking this chemokine increases the effectiveness of chemotherapy. CCL2 expression is also elevated by radiotherapy in breast cancer [107], colon cancer [258], head and neck squamous cell carcinoma [138], and pancreatic ductal adenocarcinoma [259], which leads to the resistance of these cells to radiotherapy $[138,258-260]$ and causes their migration and then metastasis [261]. In addition, a radiotherapy-induced increase in CCL2 expression leads to neuroinflammation [262,263] and vascular dysfunction which leads to impaired lung function [264]. This indicates that the effectiveness of radiotherapy may be enhanced by the use of CCL2-neutralizing antibodies or CCR2 antagonists.

On the other hand, an increased expression of CCL2 and CCL7 has shown anti-tumor effects in cervical carcinoma [150], glioma [146] and mastocytoma [149] induced by gene therapy in laboratory 
animals. These effects included tumor infiltration by CD4+ and CD8+ cells [148,149], and NK cells $[146,148,150]$. CCL2 also causes tumor infiltration by type 1 cytotoxic $\gamma \delta$ T lymphocytes in melanoma [11] and by cytotoxic T lymphocytes in colon cancer [147]. As all the aforementioned cells have anti-cancer properties, in some tumors, gene therapy can be used to increase the expression of CCL2, which in turn will enhance the accumulation of anti-cancer immune cells in the tumor. In contrast, in some tumors, such as in non-small cell lung cancer, CCL2 participates in tumor immune evasion $[265,266]$. In this case, the effectiveness of immunotherapy can be increased by the use of CCL2 neutralizing antibodies.

Compared to other chemokines, there are few studies exploring the role of eotaxins (CCL11, CCL24, and CCL26) in tumors and little has been published on therapies directed against these chemokines. However, some tumors, including colorectal cancer, have been reported to show an increased expression of eotaxins [267], which indicates the potential benefits of immunotherapy in which anti-tumor cells will have an increased expression of CCR3, a receptor for eotaxins [267]. Such cells will accumulate in tumors exhibiting an increased expression of ligands for this receptor when compared to normal tissue.

Animal studies on inoculated tumors, such as bladder cancer [268] and renal cell carcinoma [269], showed the anti-tumor effects of mogamulizumab or Affi- 5 (monoclonal antibodies targeting CCR4) which reduced the number of Treg and increased the number of NK cells and CD4+ T cells in the tumor. Another therapeutic approach is the transduction of CCR4 to cytotoxic T cells [270], lymphocytes which accumulate in a tumor with a high expression of CCR4 ligands, for example, in pancreatic cancer [270], where they destroy cancer cells. In some cancers, an increased expression of CCR4 ligands (CCL17 and CCL22) in a tumor may play an anti-tumor role in colon carcinoma [212], lung cancer [271], ovarian cancer [272] and melanoma [211,272], resulting in an increase in CD4+ T cells and CD8+ T cells. An increased expression of CCL17 and CCL22 is consistent with the prognosis for patients with colon, lung, and ovarian cancers-the higher the expression of these chemokines in these tumors, the better the prognosis $[8,9,229]$.

Clinical trials were also carried out in patients with various solid tumors who were administered mogamulizumab (KW-0761) [273,274], a defucosylated humanized monoclonal antibody targeting CCR4. This therapy led to a decrease in the number of Treg in the blood and caused changes in the cancer microenvironment which facilitated the effectiveness of immunotherapy. Mogamulizumab has also shown promising results in clinical trials involving patients with adult T-cell leukemia/lymphoma $[275,276]$, cutaneous T-cell lymphoma $[277,278]$ and peripheral T-cell lymphoma $[275,277]$. The use of mogamulizumab is also postulated in the treatment of the Epstein-Barr virus (EBV)-associated T/NK-cell lymphoproliferative diseases due to the expression of CCR4 in cells infected with EBV [279].

\section{Conclusions}

CC chemokines are an important component of the tumor microenvironment. Produced by tumor cells and tumor-associated cells such as CAF, TAM, and TAN, CC chemokines increase the proliferation, migration, and invasion of cancer cells, and induce their drug resistance. If a specific CC chemokine receptor is expressed on a circulating cancer cell, it will migrate to organs showing a high expression of the ligand of that receptor. In a similar way, CC chemokines recruit tumor-associated cells into the tumor niche-this mode of action of CC chemokines is local and depends on other factors in the tumor microenvironment. Yet although the recruited tumor-associated cells can enhance the growth of a tumor, some of them (namely, TIL), do have anti-cancer properties. This shows the importance of adjusting the therapeutic approach to the specific context in which a given CC chemokine operates. Therapies should try to use the anti-cancer properties of a given chemokine or suppress its pro-cancer properties. For example, they may increase the expression of a given chemokine in a tumor and then apply immunotherapy, in which anti-cancer immune cells accumulate in the tumor via this chemokine. 
On the other hand, they may also concentrate on blocking chemokines responsible for tumor immune evasion, and only then use immunotherapy.

Author Contributions: J.K.: writing—original draft preparation; K.K.: investigation; D.S.: investigation; R.B.: investigation; I.G.: investigation; D.C.: funding acquisition; I.B.-B.: writing-review and editing. All authors have read and agreed to the published version of the manuscript.

Funding: This study was supported by the statutory budget of the Department of Biochemistry and Medical Chemistry Pomeranian Medical University in Szczecin, Poland.

Conflicts of Interest: The authors declare no conflict of interest.

$\begin{array}{ll}\text { Abbreviations } \\ \text { CAF } & \text { cancer-associated fibroblasts } \\ \text { CCL } & \text { CC motif chemokine ligand } \\ \text { CCR } & \text { CC motif chemokine receptor } \\ \text { EMT } & \text { epithelial-to-mesenchymal transition } \\ \text { IL } & \text { interleukin } \\ \text { MDSC } & \text { myeloid-derived suppressor cells } \\ \text { MMP } & \text { matrix metalloproteinase } \\ \text { MSC } & \text { mesenchymal stem cells } \\ \text { NF- } k B & \text { nuclear factor } \kappa \text { B } \\ \text { TAM } & \text { tumor-associated macrophages } \\ \text { TAN } & \text { tumor-associated neutrophils } \\ \text { Th17 } & \text { T helper 17 } \\ \text { TIL } & \text { tumor-infiltrating lymphocytes } \\ T_{\text {reg }} & \text { regulatory T cells } \\ \text { VEGF } & \text { vascular endothelial growth factor }\end{array}$

\section{References}

1. Hanahan, D.; Weinberg, R.A. The hallmarks of cancer. Cell 2000, 100, 57-70. [CrossRef]

2. Hanahan, D.; Weinberg, R.A. Hallmarks of cancer: The next generation. Cell 2011, 144, 646-674. [CrossRef]

3. Liu, Q.; Yang, C.; Wang, S.; Shi, D.; Wei, C.; Song, J.; Lin, X.; Dou, R.; Bai, J.; Xiang, Z.; et al. Wnt5a-induced M2 polarization of tumor-associated macrophages via IL-10 promotes colorectal cancer progression. Cell Commun. Signal. 2020, 18, 51. [CrossRef] [PubMed]

4. Wang, Z.; Yang, Y.; Cui, Y.; Wang, C.; Lai, Z.; Li, Y.; Zhang, W.; Mustonen, H.; Puolakkainen, P.; Ye, Y.; et al. Tumor-associated macrophages regulate gastric cancer cell invasion and metastasis through TGFß2/NF-kB/Kindlin-2 axis. Chin. J. Cancer Res. 2020, 32, 72-88. [CrossRef] [PubMed]

5. Wu, H.; Zhang, X.; Han, D.; Cao, J.; Tian, J. Tumour-associated macrophages mediate the invasion and metastasis of bladder cancer cells through CXCL8. Peer] 2020, 8, e8721. [CrossRef] [PubMed]

6. Zlotnik, A.; Yoshie, O. Chemokines: A new classification system and their role in immunity. Immunity 2000, 12, 121-127. [CrossRef]

7. Hughes, C.E.; Nibbs, R.J.B. A guide to chemokines and their receptors. FEBS J. 2018, 285, 2944-2971. [CrossRef]

8. Uhlén, M.; Fagerberg, L.; Hallström, B.M.; Lindskog, C.; Oksvold, P.; Mardinoglu, A.; Sivertsson, Å; Kampf, C.; Sjöstedt, E.; Asplund, A.; et al. Proteomics. Tissue-based map of the human proteome. Science 2015, 347, 1260419. [CrossRef] [PubMed]

9. Uhlen, M.; Zhang, C.; Lee, S.; Sjöstedt, E.; Fagerberg, L.; Bidkhori, G.; Benfeitas, R.; Arif, M.; Liu, Z.; Edfors, F.; et al. A pathology atlas of the human cancer transcriptome. Science 2017, 357, eaan2507. [CrossRef] [PubMed]

10. Iannello, A.; Thompson, T.W.; Ardolino, M.; Lowe, S.W.; Raulet, D.H. p53-dependent chemokine production by senescent tumor cells supports NKG2D-dependent tumor elimination by natural killer cells. J. Exp. Med. 2013, 210, 2057-2069. [CrossRef] [PubMed]

11. Lança, T.; Costa, M.F.; Gonçalves-Sousa, N.; Rei, M.; Grosso, A.R.; Penido, C.; Silva-Santos, B. Protective role of the inflammatory CCR2/CCL2 chemokine pathway through recruitment of type 1 cytotoxic $\gamma \delta$ T lymphocytes to tumor beds. J. Immunol. 2013, 190, 6673-6680. [CrossRef] [PubMed] 
12. Bartneck, M.; Schrammen, P.L.; Möckel, D.; Govaere, O.; Liepelt, A.; Krenkel, O.; Ergen, C.; McCain, M.V.; Eulberg, D.; Luedde, T.; et al. The CCR2+ Macrophage Subset Promotes Pathogenic Angiogenesis for Tumor Vascularization in Fibrotic Livers. Cell Mol. Gastroenterol. Hepatol. 2019, 7, 371-390. [CrossRef]

13. Li, F.; Kitajima, S.; Kohno, S.; Yoshida, A.; Tange, S.; Sasaki, S.; Okada, N.; Nishimoto, Y.; Muranaka, H.; Nagatani, N.; et al. Retinoblastoma Inactivation Induces a Protumoral Microenvironment via Enhanced CCL2 Secretion. Cancer Res. 2019, 79, 3903-3915. [CrossRef] [PubMed]

14. Korbecki, J.; Grochans, S.; Gutowska, I.; Barczak, K.; Baranowska-Bosiacka, I. CC Chemokines in a Tumor: A Review of Pro-Cancer and Anti-Cancer Properties of Receptors CCR5, CCR6, CCR7, CCR8, CCR9, and CCR10 Ligands. Int. J. Mol. Sci. 2020, 21, 7619. [CrossRef]

15. Schulz-Knappe, P.; Mägert, H.J.; Dewald, B.; Meyer, M.; Cetin, Y.; Kubbies, M.; Tomeczkowski, J.; Kirchhoff, K.; Raida, M.; Adermann, K.; et al. HCC-1, a novel chemokine from human plasma. J. Exp. Med. 1996, 183, 295-299. [CrossRef]

16. Tsou, C.L.; Gladue, R.P.; Carroll, L.A.; Paradis, T.; Boyd, J.G.; Nelson, R.T.; Neote, K.; Charo, I.F. Identification of C-C chemokine receptor 1 (CCR1) as the monocyte hemofiltrate C-C chemokine (HCC)-1 receptor. J. Exp. Med. 1998, 188, 603-608. [CrossRef]

17. Detheux, M.; Ständker, L.; Vakili, J.; Münch, J.; Forssmann, U.; Adermann, K.; Pöhlmann, S.; Vassart, G.; Kirchhoff, F.; Parmentier, M.; et al. Natural proteolytic processing of hemofiltrate CC chemokine 1 generates a potent CC chemokine receptor (CCR)1 and CCR5 agonist with anti-HIV properties. J. Exp. Med. 2000, 192, 1501-1508. [CrossRef]

18. Münch, J.; Ständker, L.; Pöhlmann, S.; Baribaud, F.; Papkalla, A.; Rosorius, O.; Stauber, R.; Sass, G.; Heveker, N.; Adermann, K.; et al. Hemofiltrate CC chemokine 1[9-74] causes effective internalization of CCR5 and is a potent inhibitor of R5-tropic human immunodeficiency virus type 1 strains in primary T cells and macrophages. Antimicrob. Agents Chemother. 2002, 46, 982-990. [CrossRef]

19. Struyf, S.; Stoops, G.; Van Coillie, E.; Gouwy, M.; Schutyser, E.; Lenaerts, J.P.; Fiten, P.; Van Aelst, I.; Proost, P.; Opdenakker, G.; et al. Gene cloning of a new plasma CC chemokine, activating and attracting myeloid cells in synergy with other chemoattractants. Biochemistry 2001, 40, 11715-11722. [CrossRef] [PubMed]

20. Vakili, J.; Ständker, L.; Detheux, M.; Vassart, G.; Forssmann, W.G.; Parmentier, M. Urokinase plasminogen activator and plasmin efficiently convert hemofiltrate CC chemokine 1 into its active. J. Immunol. 2001, 167, 3406-3413. [CrossRef]

21. Blain, K.Y.; Kwiatkowski, W.; Zhao, Q.; La Fleur, D.; Naik, C.; Chun, T.W.; Tsareva, T.; Kanakaraj, P.; Laird, M.W.; Shah, R.; et al. Structural and functional characterization of CC chemokine CCL14. Biochemistry 2007, 46, 10008-10015. [CrossRef]

22. Mortier, A.; Van Damme, J.; Proost, P. Regulation of chemokine activity by posttranslational modification. Pharmacol. Ther. 2008, 120, 197-217. [CrossRef]

23. Grünberg, M.; Quandt, D.; Cynis, H.; Demuth, H.U.; Kindermann, A.; Magdolen, V.; Forssmann, W.G.; Seliger, B.; Mägert, H.J. Kallikrein-related peptidases are activators of the CC chemokine CCL14. Eur. J. Immunol. 2018, 48, 1592-1594. [CrossRef] [PubMed]

24. Savino, B.; Borroni, E.M.; Torres, N.M.; Proost, P.; Struyf, S.; Mortier, A.; Mantovani, A.; Locati, M.; Bonecchi, R. Recognition versus adaptive up-regulation and degradation of CC chemokines by the chemokine decoy receptor D6 are determined by their N-terminal sequence. J. Biol. Chem. 2009, 284, 26207-26215. [CrossRef]

25. Wu, F.Y.; Ou, Z.L.; Feng, L.Y.; Luo, J.M.; Wang, L.P.; Shen, Z.Z.; Shao, Z.M. Chemokine decoy receptor d6 plays a negative role in human breast cancer. Mol. Cancer Res. 2008, 6, 1276-1288. [CrossRef]

26. Langenes, V.; Svensson, H.; Börjesson, L.; Gustavsson, B.; Bemark, M.; Sjöling, Å.; Quiding-Järbrink, M. Expression of the chemokine decoy receptor D6 is decreased in colon adenocarcinomas. Cancer Immunol. Immunother. 2013, 62, 1687-1695. [CrossRef]

27. Massara, M.; Bonavita, O.; Mantovani, A.; Locati, M.; Bonecchi, R. Atypical chemokine receptors in cancer: Friends or foes? J. Leukoc. Biol. 2016, 99, 927-933. [CrossRef]

28. Hannan, N.J.; Salamonsen, L.A. CX3CL1 and CCL14 regulate extracellular matrix and adhesion molecules in the trophoblast: Potential roles in human embryo implantation. Biol. Reprod. 2008, 79, 58-65. [CrossRef] 
29. Zhu, M.; Xu, W.; Wei, C.; Huang, J.; Xu, J.; Zhang, Y.; Zhao, Y.; Chen, J.; Dong, S.; Liu, B.; et al. CCL14 serves as a novel prognostic factor and tumor suppressor of HCC by modulating cell cycle and promoting apoptosis. Cell Death Dis. 2019, 10, 796. [CrossRef]

30. Gu, Y.; Li, X.; Bi, Y.; Zheng, Y.; Wang, J.; Li, X.; Huang, Z.; Chen, L.; Huang, Y.; Huang, Y. CCL14 is a prognostic biomarker and correlates with immune infiltrates in hepatocellular carcinoma. Aging (Albany NY) 2020, 12, 784-807. [CrossRef]

31. Li, Q.; Shi, L.; Gui, B.; Yu, W.; Wang, J.; Zhang, D.; Han, X.; Yao, Z.; Shang, Y. Binding of the JmjC demethylase JARID1B to LSD1/NuRD suppresses angiogenesis and metastasis in breast cancer cells by repressing chemokine CCL14. Cancer Res. 2011, 71, 6899-6908. [CrossRef]

32. Akram, I.G.; Georges, R.; Hielscher, T.; Adwan, H.; Berger, M.R. The chemokines CCR1 and CCRL2 have a role in colorectal cancer liver metastasis. Tumour. Biol. 2016, 37, 2461-2471. [CrossRef]

33. Li, Y.; Zheng, Y.; Li, T.; Wang, Q.; Qian, J.; Lu, Y.; Zhang, M.; Bi, E.; Yang, M.; Reu, F.; et al. Chemokines CCL2, 3, 14 stimulate macrophage bone marrow homing, proliferation, and polarization in multiple myeloma. Oncotarget 2015, 6, 24218-24229. [CrossRef]

34. Coulin, F.; Power, C.A.; Alouani, S.; Peitsch, M.C.; Schroeder, J.M.; Moshizuki, M.; Clark-Lewis, I.; Wells, T.N. Characterisation of macrophage inflammatory protein-5/human CC cytokine-2, a member of the macrophage-inflammatory-protein family of chemokines. Eur. J. Biochem. 1997, 248, 507-515. [CrossRef]

35. Youn, B.S.; Zhang, S.M.; Lee, E.K.; Park, D.H.; Broxmeyer, H.E.; Murphy, P.M.; Locati, M.; Pease, J.E.; Kim, K.K.; Antol, K.; et al. Molecular cloning of leukotactin-1: A novel human beta-chemokine, a chemoattractant for neutrophils, monocytes, and lymphocytes, and a potent agonist at CC chemokine receptors 1 and 3. J. Immunol. 1997, 159, 5201-5205.

36. Pardigol, A.; Forssmann, U.; Zucht, H.D.; Loetscher, P.; Schulz-Knappe, P.; Baggiolini, M.; Forssmann, W.G.; Mägert, H.J. HCC-2, a human chemokine: Gene structure, expression pattern, and biological activity. Proc. Natl. Acad. Sci. USA 1998, 95, 6308-6313. [CrossRef]

37. Berahovich, R.D.; Miao, Z.; Wang, Y.; Premack, B.; Howard, M.C.; Schall, T.J. Proteolytic activation of alternative CCR1 ligands in inflammation. J. Immunol. 2005, 174, 7341-7351. [CrossRef]

38. Starr, A.E.; Dufour, A.; Maier, J.; Overall, C.M. Biochemical analysis of matrix metalloproteinase activation of chemokines CCL15 and CCL23 and increased glycosaminoglycan binding of CCL16. J. Biol. Chem. 2012, 287, 5848-5860. [CrossRef]

39. Li, Y.; Wu, J.; Zhang, W.; Zhang, N.; Guo, H. Identification of serum CCL15 in hepatocellular carcinoma. Br. J. Cancer 2013, 108, 99-106. [CrossRef]

40. Li, Y.; Yu, H.P.; Zhang, P. CCL15 overexpression predicts poor prognosis for hepatocellular carcinoma. Hepatol. Int. 2016, 10, 488-492. [CrossRef] [PubMed]

41. Yin, X.; Han, S.; Song, C.; Zou, H.; Wei, Z.; Xu, W.; Ran, J.; Tang, C.; Wang, Y.; Cai, Y.; et al. Metformin enhances gefitinib efficacy by interfering with interactions between tumor-associated macrophages and head and neck squamous cell carcinoma cells. Cell Oncol. (Dordr.) 2019, 42, 459-475. [CrossRef] [PubMed]

42. Kominsky, S.L.; Abdelmagid, S.M.; Doucet, M.; Brady, K.; Weber, K.L. Macrophage inflammatory protein-1 delta: A novel osteoclast stimulating factor secreted by renal cell carcinoma bone metastasis. Cancer Res. 2008, 68, 1261-1266. [CrossRef]

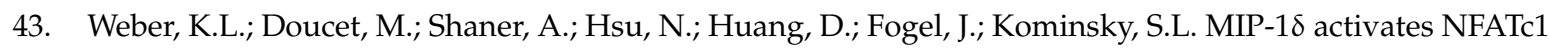
and enhances osteoclastogenesis: Involvement of both PLC $\gamma 2$ and NFKB signaling. PLoS ONE 2012, 7, e40799. [CrossRef]

44. Hwang, J.; Kim, C.W.; Son, K.N.; Han, K.Y.; Lee, K.H.; Kleinman, H.K.; Ko, J.; Na, D.S.; Kwon, B.S.; Gho, Y.S.; et al. Angiogenic activity of human CC chemokine CCL15 in vitro and in vivo. FEBS Lett. 2004, 570, 47-51. [CrossRef]

45. Inamoto, S.; Itatani, Y.; Yamamoto, T.; Minamiguchi, S.; Hirai, H.; Iwamoto, M.; Hasegawa, S.; Taketo, M.M.; Sakai, Y.; Kawada, K. Loss of SMAD4 Promotes Colorectal Cancer Progression by Accumulation of Myeloid-Derived Suppressor Cells through the CCL15-CCR1 Chemokine Axis. Clin. Cancer Res. 2016, 22, 492-501. [CrossRef] 
46. Liu, L.Z.; Zhang, Z.; Zheng, B.H.; Shi, Y.; Duan, M.; Ma, L.J.; Wang, Z.C.; Dong, L.Q.; Dong, P.P.; Shi, J.Y.; et al. CCL15 Recruits Suppressive Monocytes to Facilitate Immune Escape and Disease Progression in Hepatocellular Carcinoma. Hepatology 2019, 69, 143-159. [CrossRef]

47. Gao, Y.; Zhou, Z.; Lu, S.; Huang, X.; Zhang, C.; Jiang, R.; Yao, A.; Sun, B.; Wang, X. Chemokine CCL15 Mediates Migration of Human Bone Marrow-Derived Mesenchymal Stem Cells Toward Hepatocellular Carcinoma. Stem. Cells 2016, 34, 1112-1122. [CrossRef]

48. Yamamoto, T.; Kawada, K.; Itatani, Y.; Inamoto, S.; Okamura, R.; Iwamoto, M.; Miyamoto, E.; Chen-Yoshikawa, T.F.; Hirai, H.; Hasegawa, S.; et al. Loss of SMAD4 Promotes Lung Metastasis of Colorectal Cancer by Accumulation of CCR1+ Tumor-Associated Neutrophils through CCL15-CCR1 Axis. Clin. Cancer Res. 2017, 23, 833-844. [CrossRef]

49. Yang, J.Y.; Spanaus, K.S.; Widmer, U. Cloning, characterization and genomic organization of LCC-1 (scya16), a novel human CC chemokine expressed in liver. Cytokine 2000, 12, 101-109. [CrossRef]

50. Musso, T.; Cappello, P.; Stornello, S.; Ravarino, D.; Caorsi, C.; Otero, K.; Novelli, F.; Badolato, R.; Giovarelli, M. IL-10 enhances CCL2 release and chemotaxis induced by CCL16 in human monocytes. Int. J. Immunopathol. Pharmacol. 2005, 18, 339-349. [CrossRef]

51. Nomiyama, H.; Hieshima, K.; Nakayama, T.; Sakaguchi, T.; Fujisawa, R.; Tanase, S.; Nishiura, H.; Matsuno, K.; Takamori, H.; Tabira, Y.; et al. Human CC chemokine liver-expressed chemokine/CCL16 is a functional ligand for CCR1, CCR2 and CCR5, and constitutively expressed by hepatocytes. Int. Immunol. 2001, 13, 1021-1029. [CrossRef]

52. Howard, O.M.; Dong, H.F.; Shirakawa, A.K.; Oppenheim, J.J. LEC induces chemotaxis and adhesion by interacting with CCR1 and CCR8. Blood 2000, 96, 840-845. [CrossRef]

53. Strasly, M.; Doronzo, G.; Cappello, P.; Valdembri, D.; Arese, M.; Mitola, S.; Moore, P.; Alessandri, G.; Giovarelli, M.; Bussolino, F. CCL16 activates an angiogenic program in vascular endothelial cells. Blood 2004, 103, 40-49. [CrossRef]

54. Kim, I.S.; Jang, S.W.; Sung, H.J.; Lee, J.S.; Ko, J. Differential CCR1-mediated chemotaxis signaling induced by human CC chemokine HCC-4/CCL16 in HOS cells. FEBS Lett. 2005, 579, 6044-6048. [CrossRef]

55. Nakayama, T.; Kato, Y.; Hieshima, K.; Nagakubo, D.; Kunori, Y.; Fujisawa, T.; Yoshie, O. Liver-expressed chemokine/CC chemokine ligand 16 attracts eosinophils by interacting with histamine H4 receptor. J. Immunol. 2004, 173, 2078-2083. [CrossRef]

56. Cappello, P.; Caorsi, C.; Bosticardo, M.; De Angelis, S.; Novelli, F.; Forni, G.; Giovarelli, M. CCL16/LEC powerfully triggers effector and antigen-presenting functions of macrophages and enhances T cell cytotoxicity. J. Leukoc. Biol. 2004, 75, 135-142. [CrossRef]

57. Cappello, P.; Fraone, T.; Barberis, L.; Costa, C.; Hirsch, E.; Elia, A.R.; Caorsi, C.; Musso, T.; Novelli, F.; Giovarelli, M. CC-chemokine ligand 16 induces a novel maturation program in human immature monocyte-derived dendritic cells. J. Immunol. 2006, 177, 6143-6151. [CrossRef]

58. Giovarelli, M.; Cappello, P.; Forni, G.; Salcedo, T.; Moore, P.A.; LeFleur, D.W.; Nardelli, B.; Di Carlo, E.; Lollini, P.L.; Ruben, S.; et al. Tumor rejection and immune memory elicited by locally released LEC chemokine are associated with an impressive recruitment of APCs, lymphocytes, and granulocytes. J. Immunol. 2000, 164, 3200-3206. [CrossRef]

59. Li, J.; Hu, P.; Khawli, L.A.; Epstein, A.L. Complete regression of experimental solid tumors by combination LEC/chTNT-3 immunotherapy and CD25(+) T-cell depletion. Cancer Res. 2003, 63, 8384-8392.

60. Guiducci, C.; Di Carlo, E.; Parenza, M.; Hitt, M.; Giovarelli, M.; Musiani, P.; Colombo, M.P. Intralesional injection of adenovirus encoding CC chemokine ligand 16 inhibits mammary tumor growth and prevents metastatic-induced death after surgical removal of the treated primary tumor. J. Immunol. 2004, 172, 4026-4036. [CrossRef]

61. Caorsi, C.; Cappello, P.; Ceruti, P.; Amici, A.; Marchini, C.; Novelli, F.; Forni, G.; Giovarelli, M. CCL16 enhances the CD8+ and CD4+ T cell reactivity to human HER-2 elicited by dendritic cells loaded with rat ortholog HER-2. Int. J. Immunopathol. Pharmacol. 2008, 21, 867-877. [CrossRef]

62. Matsumoto, K.; Fukuda, S.; Hashimoto, N.; Saito, H. Human eosinophils produce and release a novel chemokine, CCL23, in vitro. Int. Arch. Allergy Immunol. 2011, 155 (Suppl. 1), 34-39. [CrossRef]

63. Nardelli, B.; Morahan, D.K.; Bong, G.W.; Semenuk, M.A.; Kreider, B.L.; Garotta, G. Dendritic cells and MPIF-1: Chemotactic activity and inhibition of endogenous chemokine production by IFN-gamma and CD40 ligation. J. Leukoc. Biol. 1999, 65, 822-828. [CrossRef] [PubMed] 
64. Forssmann, U.; Delgado, M.B.; Uguccioni, M.; Loetscher, P.; Garotta, G.; Baggiolini, M. CKbeta8, a novel CC chemokine that predominantly acts on monocytes. FEBS Lett. 1997, 408, 211-216. [CrossRef]

65. Patel, V.P.; Kreider, B.L.; Li, Y.; Li, H.; Leung, K.; Salcedo, T.; Nardelli, B.; Pippalla, V.; Gentz, S.; Thotakura, R.; et al. Molecular and functional characterization of two novel human C-C chemokines as inhibitors of two distinct classes of myeloid progenitors. J. Exp. Med. 1997, 185, 1163-1172. [CrossRef] [PubMed]

66. Macphee, C.H.; Appelbaum, E.R.; Johanson, K.; Moores, K.E.; Imburgia, C.S.; Fornwald, J.; Berkhout, T.; Brawner, M.; Groot, P.H.; O'Donnell, K.; et al. Identification of a truncated form of the CC chemokine CK beta-8 demonstrating greatly enhanced biological activity. J. Immunol. 1998, 161, 6273-6279.

67. Youn, B.S.; Zhang, S.M.; Broxmeyer, H.E.; Cooper, S.; Antol, K.; Fraser, M., Jr.; Kwon, B.S. Characterization of CKbeta8 and CKbeta8-1: Two alternatively spliced forms of human beta-chemokine, chemoattractants for neutrophils, monocytes, and lymphocytes, and potent agonists at CC chemokine receptor 1. Blood 1998, 91, 3118-3126. [CrossRef]

68. Nardelli, B.; Tiffany, H.L.; Bong, G.W.; Yourey, P.A.; Morahan, D.K.; Li, Y.; Murphy, P.M.; Alderson, R.F. Characterization of the signal transduction pathway activated in human monocytes and dendritic cells by MPIF-1, a specific ligand for CC chemokine receptor 1. J. Immunol. 1999, 162, 435-444.

69. Miao, Z.; Premack, B.A.; Wei, Z.; Wang, Y.; Gerard, C.; Showell, H.; Howard, M.; Schall, T.J.; Berahovich, R. Proinflammatory proteases liberate a discrete high-affinity functional FPRL1 (CCR12) ligand from CCL23. J. Immunol. 2007, 178, 7395-7404. [CrossRef]

70. Han, I.S.; Ra, J.S.; Kim, M.W.; Lee, E.A.; Jun, H.Y.; Park, S.K.; Kwon, B.S. Differentiation of CD34+ cells from human cord blood and murine bone marrow is suppressed by C6 beta-chemokines. Mol. Cells 2003, 15, 176-180.

71. Çelik, H.; Lindblad, K.E.; Popescu, B.; Gui, G.; Goswami, M.; Valdez, J.; DeStefano, C.; Lai, C.; Thompson, J.; Ghannam, J.Y.; et al. Highly multiplexed proteomic assessment of human bone marrow in acute myeloid leukemia. Blood Adv. 2020, 4, 367-379. [CrossRef]

72. Kim, J.; Kim, Y.S.; Ko, J. CKbeta8/CCL23 and its isoform CKbeta8-1 induce up-regulation of cyclins via the G(i)/G(o) protein/PLC/PKCdelta/ERK leading to cell-cycle progression. Cytokine 2010, 50, 42-49. [CrossRef]

73. Krishnan, V.; Tallapragada, S.; Schaar, B.; Kamat, K.; Chanana, A.M.; Zhang, Y.; Patel, S.; Parkash, V.; Rinker-Schaeffer, C.; Folkins, A.K.; et al. Omental macrophages secrete chemokine ligands that promote ovarian cancer colonization of the omentum via CCR1. Commun. Biol. 2020, 3, 524. [CrossRef]

74. Votta, B.J.; White, J.R.; Dodds, R.A.; James, I.E.; Connor, J.R.; Lee-Rykaczewski, E.; Eichman, C.F.; Kumar, S.; Lark, M.W.; Gowen, M. CKbeta-8 [CCL23], a novel CC chemokine, is chemotactic for human osteoclast precursors and is expressed in bone tissues. J. Cell Physiol. 2000, 183, 196-207. [CrossRef]

75. Hwang, J.; Son, K.N.; Kim, C.W.; Ko, J.; Na, D.S.; Kwon, B.S.; Gho, Y.S.; Kim, J. Human CC chemokine CCL23, a ligand for CCR1, induces endothelial cell migration and promotes angiogenesis. Cytokine 2005, 30, 254-263. [CrossRef]

76. Son, K.N.; Hwang, J.; Kwon, B.S.; Kim, J. Human CC chemokine CCL23 enhances expression of matrix metalloproteinase-2 and invasion of vascular endothelial cells. Biochem. Biophys. Res. Commun. 2006, 340, 498-504. [CrossRef] [PubMed]

77. Han, K.Y.; Kim, C.W.; Lee, T.H.; Son, Y.; Kim, J. CCL23 up-regulates expression of KDR/Flk-1 and potentiates VEGF-induced proliferation and migration of human endothelial cells. Biochem. Biophys. Res. Commun. 2009, 382, 124-128. [CrossRef]

78. Monteclaro, F.S.; Charo, I.F. The amino-terminal domain of CCR2 is both necessary and sufficient for high affinity binding of monocyte chemoattractant protein 1. Receptor activation by a pseudo-tethered ligand. J. Biol. Chem. 1997, 272, 23186-23190. [CrossRef]

79. Combadiere, C.; Ahuja, S.K.; Van Damme, J.; Tiffany, H.L.; Gao, J.L.; Murphy, P.M. Monocyte chemoattractant protein-3 is a functional ligand for CC chemokine receptors 1 and 2B. J. Biol. Chem. 1995, 270, 29671-29675. [PubMed]

80. Berkhout, T.A.; Sarau, H.M.; Moores, K.; White, J.R.; Elshourbagy, N.; Appelbaum, E.; Reape, R.J.; Brawner, M.; Makwana, J.; Foley, J.J.; et al. Cloning, in vitro expression, and functional characterization of a novel human $\mathrm{CC}$ chemokine of the monocyte chemotactic protein (MCP) family (MCP-4) that binds and signals through the CC chemokine receptor 2B. J. Biol. Chem. 1997, 272, 16404-16413. [CrossRef]

81. Gong, X.; Gong, W.; Kuhns, D.B.; Ben-Baruch, A.; Howard, O.M.; Wang, J.M. Monocyte chemotactic protein-2 (MCP-2) uses CCR1 and CCR2B as its functional receptors. J. Biol. Chem. 1997, 272, 11682-11685. [CrossRef] 
82. Garcia-Zepeda, E.A.; Combadiere, C.; Rothenberg, M.E.; Sarafi, M.N.; Lavigne, F.; Hamid, Q.; Murphy, P.M.; Luster, A.D. Human monocyte chemoattractant protein (MCP)-4 is a novel CC chemokine with activities on monocytes, eosinophils, and basophils induced in allergic and nonallergic inflammation that signals through the CC chemokine receptors (CCR)-2 and -3. J. Immunol. 1996, 157, 5613-5626. [PubMed]

83. Stellato, C.; Collins, P.; Ponath, P.D.; Soler, D.; Newman, W.; La Rosa, G.; Li, H.; White, J.; Schwiebert, L.M.; Bickel, C.; et al. Production of the novel C-C chemokine MCP-4 by airway cells and comparison of its biological activity to other C-C chemokines. J. Clin. Invest. 1997, 99, 926-936. [CrossRef]

84. Sun, W.; Li, W.J.; Wei, F.Q.; Wong, T.S.; Lei, W.B.; Zhu, X.L.; Li, J.; Wen, W.P. Blockade of MCP-1/CCR4 signaling-induced recruitment of activated regulatory cells evokes an antitumor immune response in head and neck squamous cell carcinoma. Oncotarget 2016, 7, 37714-37727. [CrossRef] [PubMed]

85. Blanpain, C.; Migeotte, I.; Lee, B.; Vakili, J.; Doranz, B.J.; Govaerts, C.; Vassart, G.; Doms, R.W.; Parmentier, M. CCR5 binds multiple CC-chemokines: MCP-3 acts as a natural antagonist. Blood 1999, 94, 1899-1905. [CrossRef]

86. Dagouassat, M.; Suffee, N.; Hlawaty, H.; Haddad, O.; Charni, F.; Laguillier, C.; Vassy, R.; Martin, L.; Schischmanoff, P.O.; Gattegno, L.; et al. Monocyte chemoattractant protein-1 (MCP-1)/CCL2 secreted by hepatic myofibroblasts promotes migration and invasion of human hepatoma cells. Int. J. Cancer 2010, 126, 1095-1108. [CrossRef]

87. Parody, T.R.; Stone, M.J. High level expression, activation, and antagonism of CC chemokine receptors CCR2 and CCR3 in Chinese hamster ovary cells. Cytokine 2004, 27, 38-46. [CrossRef]

88. Liang, M.; Mallari, C.; Rosser, M.; Ng, H.P.; May, K.; Monahan, S.; Bauman, J.G.; Islam, I.; Ghannam, A.; Buckman, B.; et al. Identification and characterization of a potent, selective, and orally active antagonist of the CC chemokine receptor-1. J. Biol. Chem. 2000, 275, 19000-19008. [CrossRef]

89. Heath, H.; Qin, S.; Rao, P.; Wu, L.; LaRosa, G.; Kassam, N.; Ponath, P.D.; Mackay, C.R. Chemokine receptor usage by human eosinophils. The importance of CCR3 demonstrated using an antagonistic monoclonal antibody. J. Clin. Invest. 1997, 99, 178-184. [CrossRef] [PubMed]

90. Ruffing, N.; Sullivan, N.; Sharmeen, L.; Sodroski, J.; Wu, L. CCR5 has an expanded ligand-binding repertoire and is the primary receptor used by MCP-2 on activated T cells. Cell Immunol. 1998, 189, 160-168. [CrossRef]

91. Halvorsen, E.C.; Hamilton, M.J.; Young, A.; Wadsworth, B.J.; LePard, N.E.; Lee, H.N.; Firmino, N.; Collier, J.L.; Bennewith, K.L. Maraviroc decreases CCL8-mediated migration of CCR5(+) regulatory T cells and reduces metastatic tumor growth in the lungs. Oncoimmunology 2016, 5, e1150398. [CrossRef]

92. McQuibban, G.A.; Gong, J.H.; Wong, J.P.; Wallace, J.L.; Clark-Lewis, I.; Overall, C.M. Matrix metalloproteinase processing of monocyte chemoattractant proteins generates $\mathrm{CC}$ chemokine receptor antagonists with anti-inflammatory properties in vivo. Blood 2002, 100, 1160-1167. [CrossRef] [PubMed]

93. Proost, P.; Wuyts, A.; Van Damme, J. Human monocyte chemotactic proteins-2 and -3: Structural and functional comparison with MCP-1. J. Leukoc. Biol. 1996, 59, 67-74. [CrossRef]

94. Boring, L.; Gosling, J.; Chensue, S.W.; Kunkel, S.L.; Farese, R.V., Jr.; Broxmeyer, H.E.; Charo, I.F. Impaired monocyte migration and reduced type 1 (Th1) cytokine responses in C-C chemokine receptor 2 knockout mice. J. Clin. Invest. 1997, 100, 2552-2561. [CrossRef]

95. Lu, B.; Rutledge, B.J.; Gu, L.; Fiorillo, J.; Lukacs, N.W.; Kunkel, S.L.; North, R.; Gerard, C.; Rollins, B.J. Abnormalities in monocyte recruitment and cytokine expression in monocyte chemoattractant protein 1-deficient mice. J. Exp. Med. 1998, 187, 601-608. [CrossRef]

96. Deshmane, S.L.; Kremlev, S.; Amini, S.; Sawaya, B.E. Monocyte chemoattractant protein-1 (MCP-1): An overview. Version 2. J. Interferon Cytokine Res. 2009, 29, 313-326. [CrossRef]

97. Shou, Q.; Fu, H.; Huang, X.; Yang, Y. PARP-1 controls NK cell recruitment to the site of viral infection. JCI Insight 2019, 4, e121291. [CrossRef]

98. Lamkhioued, B.; Garcia-Zepeda, E.A.; Abi-Younes, S.; Nakamura, H.; Jedrzkiewicz, S.; Wagner, L.; Renzi, P.M.; Allakhverdi, Z.; Lilly, C.; Hamid, Q.; et al. Monocyte chemoattractant protein (MCP)-4 expression in the airways of patients with asthma. Induction in epithelial cells and mononuclear cells by proinflammatory cytokines. Am. J. Respir. Crit. Care Med. 2000, 162, 723-732. [CrossRef]

99. Kalayci, O.; Sonna, L.A.; Woodruff, P.G.; Camargo, C.A., Jr.; Luster, A.D.; Lilly, C.M. Monocyte chemotactic protein-4 (MCP-4; CCL-13): A biomarker of asthma. J. Asthma 2004, 41, 27-33. [CrossRef]

100. Thomas, J.K.; Mir, H.; Kapur, N.; Bae, S.; Singh, S. CC chemokines are differentially expressed in Breast Cancer and are associated with disparity in overall survival. Sci. Rep. 2019, 9, 4014. [CrossRef] 
101. Sharma, I.; Singh, A.; Sharma, K.C.; Saxena, S. Gene Expression Profiling of Chemokines and Their Receptors in Low and High Grade Astrocytoma. Asian Pac. J. Cancer Prev. 2017, 18, 1307-1313.

102. Arnold, J.M.; Huggard, P.R.; Cummings, M.; Ramm, G.A.; Chenevix-Trench, G. Reduced expression of chemokine (C-C motif) ligand-2 (CCL2) in ovarian adenocarcinoma. Br. J. Cancer 2005, 92, 2024-2031. [CrossRef]

103. Ohta, M.; Kitadai, Y.; Tanaka, S.; Yoshihara, M.; Yasui, W.; Mukaida, N.; Haruma, K.; Chayama, K. Monocyte chemoattractant protein-1 expression correlates with macrophage infiltration and tumor vascularity in human esophageal squamous cell carcinomas. Int. J. Cancer 2002, 102, 220-224. [CrossRef]

104. Koide, N.; Nishio, A.; Sato, T.; Sugiyama, A.; Miyagawa, S. Significance of macrophage chemoattractant protein-1 expression and macrophage infiltration in squamous cell carcinoma of the esophagus. Am. J. Gastroenterol. 2004, 99, 1667-1674. [CrossRef]

105. Desai, S.; Kumar, A.; Laskar, S.; Pandey, B.N. Cytokine profile of conditioned medium from human tumor cell lines after acute and fractionated doses of gamma radiation and its effect on survival of bystander tumor cells. Cytokine 2013, 61, 54-62. [CrossRef] [PubMed]

106. Quan, J.; Morrison, N.A.; Johnson, N.W.; Gao, J. MCP-1 as a potential target to inhibit the bone invasion by oral squamous cell carcinoma. J. Cell Biochem. 2014, 115, 1787-1798. [CrossRef] [PubMed]

107. Bravatà, V.; Minafra, L.; Forte, G.I.; Cammarata, F.P.; Russo, G.; Di Maggio, F.M.; Augello, G.; Lio, D.; Gilardi, M.C. Cytokine profile of breast cell lines after different radiation doses. Int. J. Radiat. Biol. 2017, 93, 1217-1226. [CrossRef]

108. Lu, B.; Zhou, Y.; Su, Z.; Yan, A.; Ding, P. Effect of CCL2 siRNA on proliferation and apoptosis in the U251 human glioma cell line. Mol. Med. Rep. 2017, 16, 3387-3394. [CrossRef]

109. Dutta, P.; Sarkissyan, M.; Paico, K.; Wu, Y.; Vadgama, J.V. MCP-1 is overexpressed in triple-negative breast cancers and drives cancer invasiveness and metastasis. Breast Cancer Res. Treat. 2018, 170, 477-486. [CrossRef]

110. Ding, M.; He, S.J.; Yang, J. MCP-1/CCL2 Mediated by Autocrine Loop of PDGF-BB Promotes Invasion of Lung Cancer Cell by Recruitment of Macrophages Via CCL2-CCR2 Axis. J. Interferon Cytokine Res. 2019, 39, 224-232. [CrossRef]

111. Kunz, M.; Bloss, G.; Gillitzer, R.; Gross, G.; Goebeler, M.; Rapp, U.R.; Ludwig, S. Hypoxia/reoxygenation induction of monocyte chemoattractant protein-1 in melanoma cells: Involvement of nuclear factor-kappaB, stimulatory protein-1 transcription factors and mitogen-activated protein kinase pathways. Biochem. J. 2002, 366, 299-306. [CrossRef]

112. Geller, M.A.; Bui-Nguyen, T.M.; Rogers, L.M.; Ramakrishnan, S. Chemotherapy induces macrophage chemoattractant protein-1 production in ovarian cancer. Int. J. Gynecol Cancer 2010, 20, 918-925.

113. Lin, Z.Y.; Chuang, Y.H.; Chuang, W.L. Cancer-associated fibroblasts up-regulate CCL2, CCL26, IL6 and LOXL2 genes related to promotion of cancer progression in hepatocellular carcinoma cells. Biomed. Pharmacother. 2012, 66, 525-529. [CrossRef]

114. Han, E.C.; Lee, J.; Ryu, S.W.; Choi, C. Tumor-conditioned Gr-1(+)CD11b(+) myeloid cells induce angiogenesis through the synergistic action of CCL2 and CXCL16 in vitro. Biochem. Biophys. Res. Commun. 2014, 443, 1218-1225. [CrossRef]

115. Jia, X.H.; Du, Y.; Mao, D.; Wang, Z.L.; He, Z.Q.; Qiu, J.D.; Ma, X.B.; Shang, W.T.; Ding, D.; Tian, J. Zoledronic acid prevents the tumor-promoting effects of mesenchymal stem cells via MCP-1 dependent recruitment of macrophages. Oncotarget 2015, 6, 26018-26028. [CrossRef] [PubMed]

116. Mohamed, M.M.; El-Ghonaimy, E.A.; Nouh, M.A.; Schneider, R.J.; Sloane, B.F.; El-Shinawi, M. Cytokines secreted by macrophages isolated from tumor microenvironment of inflammatory breast cancer patients possess chemotactic properties. Int. J. Biochem. Cell Biol. 2014, 46, 138-147. [CrossRef]

117. Chang, A.L.; Miska, J.; Wainwright, D.A.; Dey, M.; Rivetta, C.V.; Yu, D.; Kanojia, D.; Pituch, K.C.; Qiao, J.; Pytel, P.; et al. CCL2 Produced by the Glioma Microenvironment Is Essential for the Recruitment of Regulatory T Cells and Myeloid-Derived Suppressor Cells. Cancer Res. 2016, 76, 5671-5682. [CrossRef]

118. Gabrusiewicz, K.; Rodriguez, B.; Wei, J.; Hashimoto, Y.; Healy, L.M.; Maiti, S.N.; Thomas, G.; Zhou, S.; Wang, Q.; Elakkad, A.; et al. Glioblastoma-infiltrated innate immune cells resemble M0 macrophage phenotype. JCI Insight. 2016, 1, e85841. [CrossRef]

119. Zhou, S.L.; Zhou, Z.J.; Hu, Z.Q.; Huang, X.W.; Wang, Z.; Chen, E.B.; Fan, J.; Cao, Y.; Dai, Z.; Zhou, J. Tumor-Associated Neutrophils Recruit Macrophages and T-Regulatory Cells to Promote Progression of Hepatocellular Carcinoma and Resistance to Sorafenib. Gastroenterology 2016, 150, 1646-1658.e17. [CrossRef] 
120. Silzle, T.; Kreutz, M.; Dobler, M.A.; Brockhoff, G.; Knuechel, R.; Kunz-Schughart, L.A. Tumor-associated fibroblasts recruit blood monocytes into tumor tissue. Eur. J. Immunol. 2003, 33, 1311-1320. [CrossRef]

121. Subramaniam, K.S.; Tham, S.T.; Mohamed, Z.; Woo, Y.L.; Mat Adenan, N.A.; Chung, I. Cancer-associated fibroblasts promote proliferation of endometrial cancer cells. PLoS ONE 2013, 8, e68923. [CrossRef]

122. Yang, X.; Lin, Y.; Shi, Y.; Li, B.; Liu, W.; Yin, W.; Dang, Y.; Chu, Y.; Fan, J.; He, R. FAP Promotes Immunosuppression by Cancer-Associated Fibroblasts in the Tumor Microenvironment via STAT3-CCL2 Signaling. Cancer Res. 2016, 76, 4124-4135. [CrossRef]

123. Jung, D.W.; Che, Z.M.; Kim, J.; Kim, K.; Kim, K.Y.; Williams, D.; Kim, J. Tumor-stromal crosstalk in invasion of oral squamous cell carcinoma: A pivotal role of CCL7. Int. J. Cancer 2010, 127, 332-344. [CrossRef]

124. Barbai, T.; Fejős, Z.; Puskas, L.G.; Tímár, J.; Rásó, E. The importance of microenvironment: The role of CCL8 in metastasis formation of melanoma. Oncotarget 2015, 6, 29111-29128. [CrossRef]

125. Farmaki, E.; Chatzistamou, I.; Kaza, V.; Kiaris, H. A CCL8 gradient drives breast cancer cell dissemination. Oncogene 2016, 35, 6309-6318. [CrossRef]

126. Yoshimura, T.; Imamichi, T.; Weiss, J.M.; Sato, M.; Li, L.; Matsukawa, A.; Wang, J.M. Induction of Monocyte Chemoattractant Proteins in Macrophages via the Production of Granulocyte/Macrophage Colony-Stimulating Factor by Breast Cancer Cells. Front. Immunol. 2016, 7, 2. [CrossRef]

127. Tsuyada, A.; Chow, A.; Wu, J.; Somlo, G.; Chu, P.; Loera, S.; Luu, T.; Li, A.X.; Wu, X.; Ye, W.; et al. CCL2 mediates cross-talk between cancer cells and stromal fibroblasts that regulates breast cancer stem cells. Cancer Res. 2012, 72, 2768-2779. [CrossRef]

128. Higashino, N.; Koma, Y.I.; Hosono, M.; Takase, N.; Okamoto, M.; Kodaira, H.; Nishio, M.; Shigeoka, M.; Kakeji, Y.; Yokozaki, H. Fibroblast activation protein-positive fibroblasts promote tumor progression through secretion of CCL2 and interleukin-6 in esophageal squamous cell carcinoma. Lab. Invest. 2019, 99, 777-792. [CrossRef]

129. Pausch, T.M.; Aue, E.; Wirsik, N.M.; Freire Valls, A.; Shen, Y.; Radhakrishnan, P.; Hackert, T.; Schneider, M.; Schmidt, T. Metastasis-associated fibroblasts promote angiogenesis in metastasized pancreatic cancer via the CXCL8 and the CCL2 axes. Sci. Rep. 2020, 10, 5420. [CrossRef]

130. Vickman, R.E.; Broman, M.M.; Lanman, N.A.; Franco, O.E.; Sudyanti, P.A.G.; Ni, Y.; Ji, Y.; Helfand, B.T.; Petkewicz, J.; Paterakos, M.C.; et al. Heterogeneity of human prostate carcinoma-associated fibroblasts implicates a role for subpopulations in myeloid cell recruitment. Prostate 2020, 80, 173-185. [CrossRef] [PubMed]

131. Wang, H.; Zhang, Q.; Kong, H.; Zeng, Y.; Hao, M.; Yu, T.; Peng, J.; Xu, Z.; Chen, J.; Shi, H. Monocyte chemotactic protein-1 expression as a prognosic biomarker in patients with solid tumor: A meta analysis. Int. J. Clin. Exp. Pathol. 2014, 7, 3876-3886.

132. Goede, V.; Brogelli, L.; Ziche, M.; Augustin, H.G. Induction of inflammatory angiogenesis by monocyte chemoattractant protein-1. Int. J. Cancer 1999, 82, 765-770. [CrossRef]

133. Kuroda, T.; Kitadai, Y.; Tanaka, S.; Yang, X.; Mukaida, N.; Yoshihara, M.; Chayama, K. Monocyte chemoattractant protein-1 transfection induces angiogenesis and tumorigenesis of gastric carcinoma in nude mice via macrophage recruitment. Clin. Cancer Res. 2005, 11, 7629-7636. [CrossRef]

134. Qian, B.Z.; Li, J.; Zhang, H.; Kitamura, T.; Zhang, J.; Campion, L.R.; Kaiser, E.A.; Snyder, L.A.; Pollard, J.W. CCL2 recruits inflammatory monocytes to facilitate breast-tumour metastasis. Nature 2011, 475, 222-225. [CrossRef]

135. Low-Marchelli, J.M.; Ardi, V.C.; Vizcarra, E.A.; van Rooijen, N.; Quigley, J.P.; Yang, J. Twist1 induces CCL2 and recruits macrophages to promote angiogenesis. Cancer Res. 2013, 73, 662-671. [CrossRef]

136. Roca, H.; Varsos, Z.S.; Sud, S.; Craig, M.J.; Ying, C.; Pienta, K.J. CCL2 and interleukin-6 promote survival of human CD11b+ peripheral blood mononuclear cells and induce M2-type macrophage polarization. J. Biol. Chem. 2009, 284, 34342-34354. [CrossRef]

137. Loyher, P.L.; Rochefort, J.; Baudesson de Chanville, C.; Hamon, P.; Lescaille, G.; Bertolus, C.; Guillot-Delost, M.; Krummel, M.F.; Lemoine, F.M.; Combadière, C.; et al. CCR2 Influences T Regulatory Cell Migration to Tumors and Serves as a Biomarker of Cyclophosphamide Sensitivity. Cancer Res. 2016, 76, 6483-6494. [CrossRef] 
138. Mondini, M.; Loyher, P.L.; Hamon, P.; Gerbé de Thoré, M.; Laviron, M.; Berthelot, K.; Clémenson, C.; Salomon, B.L.; Combadière, C.; Deutsch, E.; et al. CCR2-Dependent Recruitment of Tregs and Monocytes Following Radiotherapy Is Associated with TNF $\alpha$-Mediated Resistance. Cancer Immunol. Res. 2019, 7, 376-387. [CrossRef]

139. Su, X.; Ye, J.; Hsueh, E.C.; Zhang, Y.; Hoft, D.F.; Peng, G. Tumor microenvironments direct the recruitment and expansion of human Th17 cells. J. Immunol. 2010, 184, 1630-1641. [CrossRef]

140. Xu, F.; Shi, J.; Yu, B.; Ni, W.; Wu, X.; Gu, Z. Chemokines mediate mesenchymal stem cell migration toward gliomas in vitro. Oncol. Rep. 2010, 23, 1561-1567. [CrossRef]

141. Magge, S.N.; Malik, S.Z.; Royo, N.C.; Chen, H.I.; Yu, L.; Snyder, E.Y.; O’Rourke, D.M.; Watson, D.J. Role of monocyte chemoattractant protein-1 (MCP-1/CCL2) in migration of neural progenitor cells toward glial tumors. J. Neurosci. Res. 2009, 87, 1547-1555. [CrossRef]

142. Platten, M.; Kretz, A.; Naumann, U.; Aulwurm, S.; Egashira, K.; Isenmann, S.; Weller, M. Monocyte chemoattractant protein-1 increases microglial infiltration and aggressiveness of gliomas. Ann. Neurol. 2003, 54, 388-392. [CrossRef]

143. Yang, X.; Lu, P.; Ishida, Y.; Kuziel, W.A.; Fujii, C.; Mukaida, N. Attenuated liver tumor formation in the absence of CCR2 with a concomitant reduction in the accumulation of hepatic stellate cells, macrophages and neovascularization. Int. J. Cancer 2006, 118, 335-345. [CrossRef]

144. Ly, L.V.; Bronkhorst, I.H.; van Beelen, E.; Vrolijk, J.; Taylor, A.W.; Versluis, M.; Luyten, G.P.; Jager, M.J. Inflammatory cytokines in eyes with uveal melanoma and relation with macrophage infiltration. Invest. Ophthalmol. Vis. Sci. 2010, 51, 5445-5451. [CrossRef] [PubMed]

145. Chen, X.J.; Deng, Y.R.; Wang, Z.C.; Wei, W.F.; Zhou, C.F.; Zhang, Y.M.; Yan, R.M.; Liang, L.J.; Zhong, M.; Liang, L.; et al. Hypoxia-induced ZEB1 promotes cervical cancer progression via CCL8-dependent tumour-associated macrophage recruitment. Cell Death Dis. 2019, 10, 508. [CrossRef]

146. Nagai, M.; Masuzawa, T. Vaccination with MCP-1 cDNA transfectant on human malignant glioma in nude mice induces migration of monocytes and NK cells to the tumor. Int. Immunopharmacol. 2001, 1, 657-664. [CrossRef]

147. Berencsi, K.; Rani, P.; Zhang, T.; Gross, L.; Mastrangelo, M.; Meropol, N.J.; Herlyn, D.; Somasundaram, R. In vitro migration of cytotoxic $\mathrm{T}$ lymphocyte derived from a colon carcinoma patient is dependent on CCL2 and CCR2. J. Transl. Med. 2011, 9, 33. [CrossRef]

148. Nakasone, Y.; Fujimoto, M.; Matsushita, T.; Hamaguchi, Y.; Huu, D.L.; Yanaba, M.; Sato, S.; Takehara, K.; Hasegawa, M. Host-derived MCP-1 and MIP-1 $\alpha$ regulate protective anti-tumor immunity to localized and metastatic B16 melanoma. Am. J. Pathol. 2012, 180, 365-374. [CrossRef]

149. Fioretti, F.; Fradelizi, D.; Stoppacciaro, A.; Ramponi, S.; Ruco, L.; Minty, A.; Sozzani, S.; Garlanda, C.; Vecchi, A.; Mantovani, A. Reduced tumorigenicity and augmented leukocyte infiltration after monocyte chemotactic protein-3 (MCP-3) gene transfer: Perivascular accumulation of dendritic cells in peritumoral tissue and neutrophil recruitment within the tumor. J. Immunol. 1998, 161, 342-346.

150. Wetzel, K.; Menten, P.; Opdënakker, G.; Van Damme, J.; Gröne, H.J.; Giese, N.; Vecchi, A.; Sozzani, S.; Cornelis, J.J.; Rommelaere, J.; et al. Transduction of human MCP-3 by a parvoviral vector induces leukocyte infiltration and reduces growth of human cervical carcinoma cell xenografts. J. Gene Med. 2001, 3, 326-337. [CrossRef]

151. Vitiello, P.F.; Shainheit, M.G.; Allison, E.M.; Adler, E.P.; Kurt, R.A. Impact of tumor-derived CCL2 on T cell effector function. Immunol. Lett. 2004, 91, 239-245. [CrossRef]

152. Michielsen, A.J.; Hogan, A.E.; Marry, J.; Tosetto, M.; Cox, F.; Hyland, J.M.; Sheahan, K.D.; O’Donoghue, D.P.; Mulcahy, H.E.; Ryan, E.J.; et al. Tumour tissue microenvironment can inhibit dendritic cell maturation in colorectal cancer. PLoS ONE 2011, 6, e27944. [CrossRef]

153. Mou, T.; Xie, F.; Zhong, P.; Hua, H.; Lai, L.; Yang, Q.; Wang, J. MiR-345-5p functions as a tumor suppressor in pancreatic cancer by directly targeting CCL8. Biomed. Pharmacother. 2019, 111, 891-900. [CrossRef] [PubMed]

154. Yao, M.; Fang, W.; Smart, C.; Hu, Q.; Huang, S.; Alvarez, N.; Fields, P.; Cheng, N. CCR2 Chemokine Receptors Enhance Growth and Cell-Cycle Progression of Breast Cancer Cells through SRC and PKC Activation. Mol. Cancer Res. 2019, 17, 604-617. [CrossRef]

155. Zhang, X.; Chen, L.; Dang, W.Q.; Cao, M.F.; Xiao, J.F.; Lv, S.Q.; Jiang, W.J.; Yao, X.H.; Lu, H.M.; Miao, J.Y.; et al. CCL8 secreted by tumor-associated macrophages promotes invasion and stemness of glioblastoma cells via ERK1/2 signaling. Lab. Invest. 2020, 100, 619-629. [CrossRef] [PubMed] 
156. Shi, C.L.; Yu, C.H.; Zhang, Y.; Zhao, D.; Chang, X.H.; Wang, W.H. Monocyte chemoattractant protein-1 modulates invasion and apoptosis of PC-3M prostate cancer cells via regulating expression of VEGF, MMP9 and caspase-3. Asian Pac. J. Cancer Prev. 2011, 12, 555-559.

157. Natsagdorj, A.; Izumi, K.; Hiratsuka, K.; Machioka, K.; Iwamoto, H.; Naito, R.; Makino, T.; Kadomoto, S.; Shigehara, K.; Kadono, Y.; et al. CCL2 induces resistance to the antiproliferative effect of cabazitaxel in prostate cancer cells. Cancer Sci. 2019, 110, 279-288. [CrossRef]

158. Li, D.; Ji, H.; Niu, X.; Yin, L.; Wang, Y.; Gu, Y.; Wang, J.; Zhou, X.; Zhang, H.; Zhang, Q. Tumor-associated macrophages secrete CC-chemokine ligand 2 and induce tamoxifen resistance by activating PI3K/Akt/mTOR in breast cancer. Cancer Sci. 2020, 111, 47-58. [CrossRef]

159. Torres, S.; Bartolomé, R.A.; Mendes, M.; Barderas, R.; Fernandez-Aceñero, M.J.; Peláez-García, A.; Peña, C.; Lopez-Lucendo, M.; Villar-Vázquez, R.; de Herreros, A.G.; et al. Proteome profiling of cancer-associated fibroblasts identifies novel proinflammatory signatures and prognostic markers for colorectal cancer. Clin. Cancer Res. 2013, 19, 6006-6019. [CrossRef]

160. Grimm, S.; Jennek, S.; Singh, R.; Enkelmann, A.; Junker, K.; Rippaus, N.; Berndt, A.; Friedrich, K. Malignancy of bladder cancer cells is enhanced by tumor-associated fibroblasts through a multifaceted cytokine-chemokine loop. Exp. Cell Res. 2015, 335, 1-11. [CrossRef]

161. Liu, J.; Chen, S.; Wang, W.; Ning, B.F.; Chen, F.; Shen, W.; Ding, J.; Chen, W.; Xie, W.F.; Zhang, X. Cancer-associated fibroblasts promote hepatocellular carcinoma metastasis through chemokine-activated hedgehog and TGF- $\beta$ pathways. Cancer Lett. 2016, 379, 49-59. [CrossRef]

162. Lee, C.C.; Ho, H.C.; Su, Y.C.; Lee, M.S.; Hung, S.K.; Lin, C.H. MCP1-Induced Epithelial-Mesenchymal Transition in Head and Neck Cancer by AKT Activation. Anticancer Res. 2015, 35, 3299-3306. [PubMed]

163. Li, S.; Lu, J.; Chen, Y.; Xiong, N.; Li, L.; Zhang, J.; Yang, H.; Wu, C.; Zeng, H.; Liu, Y. MCP-1-induced ERK/GSK-3 $\beta /$ Snail signaling facilitates the epithelial-mesenchymal transition and promotes the migration of MCF-7 human breast carcinoma cells. Cell Mol. Immunol. 2017, 14, 621-630. [CrossRef]

164. Lee, Y.S.; Kim, S.Y.; Song, S.J.; Hong, H.K.; Lee, Y.; Oh, B.Y.; Lee, W.Y.; Cho, Y.B. Crosstalk between CCL7 and CCR3 promotes metastasis of colon cancer cells via ERK-JNK signaling pathways. Oncotarget 2016, 7, 36842-36853. [CrossRef]

165. Zhou, J.; Zheng, S.; Liu, T.; Liu, Q.; Chen, Y.; Tan, D.; Ma, R.; Lu, X. MCP2 activates NF-kB signaling pathway promoting the migration and invasion of ESCC cells. Cell Biol. Int. 2018, 42, 365-372. [CrossRef] [PubMed]

166. Mestdagt, M.; Polette, M.; Buttice, G.; Noël, A.; Ueda, A.; Foidart, J.M.; Gilles, C. Transactivation of MCP-1/CCL2 by beta-catenin/TCF-4 in human breast cancer cells. Int. J. Cancer 2006, 118, 35-42. [CrossRef]

167. Kitamura, T.; Qian, B.Z.; Soong, D.; Cassetta, L.; Noy, R.; Sugano, G.; Kato, Y.; Li, J.; Pollard, J.W. CCL2-induced chemokine cascade promotes breast cancer metastasis by enhancing retention of metastasis-associated macrophages. J. Exp. Med. 2015, 212, 1043-1059. [CrossRef] [PubMed]

168. Granot, Z.; Henke, E.; Comen, E.A.; King, T.A.; Norton, L.; Benezra, R. Tumor entrained neutrophils inhibit seeding in the premetastatic lung. Cancer Cell 2011, 20, 300-314. [CrossRef]

169. Van Golen, K.L.; Ying, C.; Sequeira, L.; Dubyk, C.W.; Reisenberger, T.; Chinnaiyan, A.M.; Pienta, K.J.; Loberg, R.D. CCL2 induces prostate cancer transendothelial cell migration via activation of the small GTPase Rac. J. Cell Biochem. 2008, 104, 1587-1597. [CrossRef]

170. Li, X.; Loberg, R.; Liao, J.; Ying, C.; Snyder, L.A.; Pienta, K.J.; McCauley, L.K. A destructive cascade mediated by CCL2 facilitates prostate cancer growth in bone. Cancer Res. 2009, 69, 1685-1692. [CrossRef]

171. Wang, N.; Docherty, F.E.; Brown, H.K.; Reeves, K.J.; Fowles, A.C.; Ottewell, P.D.; Dear, T.N.; Holen, I.; Croucher, P.I.; Eaton, C.L. Prostate cancer cells preferentially home to osteoblast-rich areas in the early stages of bone metastasis: Evidence from in vivo models. J. Bone Miner. Res. 2014, 29, 2688-2696. [CrossRef]

172. Cai, Z.; Chen, Q.; Chen, J.; Lu, Y.; Xiao, G.; Wu, Z.; Zhou, Q.; Zhang, J. Monocyte chemotactic protein 1 promotes lung cancer-induced bone resorptive lesions in vivo. Neoplasia 2009, 11, 228-236. [CrossRef]

173. He, Z.; He, J.; Liu, Z.; Xu, J.; Yi, S.F.; Liu, H.; Yang, J. MAPK11 in breast cancer cells enhances osteoclastogenesis and bone resorption. Biochimie 2014, 106, 24-32. [CrossRef]

174. Lu, Y.; Xiao, G.; Galson, D.L.; Nishio, Y.; Mizokami, A.; Keller, E.T.; Yao, Z.; Zhang, J. PTHrP-induced MCP-1 production by human bone marrow endothelial cells and osteoblasts promotes osteoclast differentiation and prostate cancer cell proliferation and invasion in vitro. Int. J. Cancer 2007, 121, 724-733. [CrossRef] 
175. He, S.; He, S.; Chen, C.H.; Deborde, S.; Bakst, R.L.; Chernichenko, N.; McNamara, W.F.; Lee, S.Y.; Barajas, F.; $\mathrm{Yu}, \mathrm{Z}$.; et al. The chemokine (CCL2-CCR2) signaling axis mediates perineural invasion. Mol. Cancer Res. 2015, 13, 380-390. [CrossRef] [PubMed]

176. Huang, T.; Fan, Q.; Wang, Y.; Cui, Y.; Wang, Z.; Yang, L.; Sun, X.; Wang, Y. Schwann Cell-Derived CCL2 Promotes the Perineural Invasion of Cervical Cancer. Front. Oncol. 2020, 10, 19. [CrossRef]

177. Salcedo, R.; Ponce, M.L.; Young, H.A.; Wasserman, K.; Ward, J.M.; Kleinman, H.K.; Oppenheim, J.J.; Murphy, W.J. Human endothelial cells express CCR2 and respond to MCP-1: Direct role of MCP-1 in angiogenesis and tumor progression. Blood 2000, 96, 34-40. [CrossRef] [PubMed]

178. Varney, M.L.; Olsen, K.J.; Mosley, R.L.; Singh, R.K. Paracrine regulation of vascular endothelial growth factor-a expression during macrophage-melanoma cell interaction: Role of monocyte chemotactic protein-1 and macrophage colony-stimulating factor. J. Interferon Cytokine Res. 2005, 25, 674-683. [CrossRef] [PubMed]

179. Jetten, N.; Verbruggen, S.; Gijbels, M.J.; Post, M.J.; De Winther, M.P.; Donners, M.M. Anti-inflammatory M2, but not pro-inflammatory M1 macrophages promote angiogenesis in vivo. Angiogenesis 2014, 17, 109-118. [CrossRef]

180. Lee, K.M.; Danuser, R.; Stein, J.V.; Graham, D.; Nibbs, R.J.; Graham, G.J. The chemokine receptors ACKR2 and CCR2 reciprocally regulate lymphatic vessel density. EMBO J. 2014, 33, 2564-2580. [CrossRef]

181. Yamaguchi, A.; Nozawa, K.; Fujishiro, M.; Kawasaki, M.; Suzuki, F.; Takamori, K.; Ogawa, H.; Takasaki, Y.; Sekigawa, I. CC motif chemokine ligand 13 is associated with rheumatoid arthritis pathogenesis. Mod. Rheumatol. 2013, 23, 856-863. [CrossRef]

182. Kitaura, M.; Nakajima, T.; Imai, T.; Harada, S.; Combadiere, C.; Tiffany, H.L.; Murphy, P.M.; Yoshie, O. Molecular cloning of human eotaxin, an eosinophil-selective CC chemokine, and identification of a specific eosinophil eotaxin receptor, CC chemokine receptor 3. J. Biol. Chem. 1996, 271, 7725-7730. [CrossRef]

183. Forssmann, U.; Uguccioni, M.; Loetscher, P.; Dahinden, C.A.; Langen, H.; Thelen, M.; Baggiolini, M. Eotaxin-2, a novel CC chemokine that is selective for the chemokine receptor CCR3, and acts like eotaxin on human eosinophil and basophil leukocytes. J. Exp. Med. 1997, 185, 2171-2176. [CrossRef]

184. White, J.R.; Imburgia, C.; Dul, E.; Appelbaum, E.; O’Donnell, K.; O’Shannessy, D.J.; Brawner, M.; Fornwald, J.; Adamou, J.; Elshourbagy, N.A.; et al. Cloning and functional characterization of a novel human CC chemokine that binds to the CCR3 receptor and activates human eosinophils. J. Leukoc. Biol. 1997, 62, 667-675. [CrossRef]

185. Kitaura, M.; Suzuki, N.; Imai, T.; Takagi, S.; Suzuki, R.; Nakajima, T.; Hirai, K.; Nomiyama, H.; Yoshie, O. Molecular cloning of a novel human CC chemokine (Eotaxin-3) that is a functional ligand of CC chemokine receptor 3. J. Biol. Chem. 1999, 274, 27975-27980. [CrossRef] [PubMed]

186. Ogilvie, P.; Bardi, G.; Clark-Lewis, I.; Baggiolini, M.; Uguccioni, M. Eotaxin is a natural antagonist for CCR2 and an agonist for CCR5. Blood 2001, 97, 1920-1924. [CrossRef]

187. Nakayama, T.; Watanabe, Y.; Oiso, N.; Higuchi, T.; Shigeta, A.; Mizuguchi, N.; Katou, F.; Hashimoto, K.; Kawada, A.; Yoshie, O. Eotaxin-3/CC chemokine ligand 26 is a functional ligand for CX3CR1. J. Immunol. 2010, 185, 6472-6479. [CrossRef]

188. Chiu, D.K.; Xu, I.M.; Lai, R.K.; Tse, A.P.; Wei, L.L.; Koh, H.Y.; Li, L.L.; Lee, D.; Lo, R.C.; Wong, C.M.; et al. Hypoxia induces myeloid-derived suppressor cell recruitment to hepatocellular carcinoma through chemokine (C-C motif) ligand 26. Hepatology 2016, 64, 797-813. [CrossRef]

189. Ogilvie, P.; Paoletti, S.; Clark-Lewis, I.; Uguccioni, M. Eotaxin-3 is a natural antagonist for CCR2 and exerts a repulsive effect on human monocytes. Blood 2003, 102, 789-794. [CrossRef]

190. Petkovic, V.; Moghini, C.; Paoletti, S.; Uguccioni, M.; Gerber, B. Eotaxin-3/CCL26 is a natural antagonist for CC chemokine receptors 1 and 5. A human chemokine with a regulatory role. J. Biol. Chem. 2004, 279, 23357-23363. [CrossRef]

191. Yamada, H.; Hirai, K.; Miyamasu, M.; Iikura, M.; Misaki, Y.; Shoji, S.; Takaishi, T.; Kasahara, T.; Morita, Y.; Ito, K. Eotaxin is a potent chemotaxin for human basophils. Biochem. Biophys. Res. Commun. 1997, 231, 365-368. [CrossRef] [PubMed]

192. Ponath, P.D.; Qin, S.; Ringler, D.J.; Clark-Lewis, I.; Wang, J.; Kassam, N.; Smith, H.; Shi, X.; Gonzalo, J.A.; Newman, W.; et al. Cloning of the human eosinophil chemoattractant, eotaxin. Expression, receptor binding, and functional properties suggest a mechanism for the selective recruitment of eosinophils. J. Clin. Invest. 1996, 97, 604-612. [CrossRef] [PubMed] 
193. Menzies-Gow, A.; Ying, S.; Sabroe, I.; Stubbs, V.L.; Soler, D.; Williams, T.J.; Kay, A.B. Eotaxin (CCL11) and eotaxin-2 (CCL24) induce recruitment of eosinophils, basophils, neutrophils, and macrophages as well as features of early- and late-phase allergic reactions following cutaneous injection in human atopic and nonatopic volunteers. J. Immunol. 2002, 169, 2712-2718. [CrossRef]

194. Provost, V.; Larose, M.C.; Langlois, A.; Rola-Pleszczynski, M.; Flamand, N.; Laviolette, M. CCL26/eotaxin-3 is more effective to induce the migration of eosinophils of asthmatics than CCL11/eotaxin-1 and CCL24/eotaxin-2. J. Leukoc. Biol. 2013, 94, 213-222. [CrossRef]

195. Cho, H.; Lim, S.J.; Won, K.Y.; Bae, G.E.; Kim, G.Y.; Min, J.W.; Noh, B.J. Eosinophils in Colorectal Neoplasms Associated with Expression of CCL11 and CCL24. J. Pathol. Transl. Med. 2016, 50, 45-51. [CrossRef]

196. Lorena, S.C.; Oliveira, D.T.; Dorta, R.G.; Landman, G.; Kowalski, L.P. Eotaxin expression in oral squamous cell carcinomas with and without tumour associated tissue eosinophilia. Oral. Dis. 2003, 9, 279-283. [CrossRef]

197. Da Silva, J.M.; Queiroz-Junior, C.M.; Batista, A.C.; Rachid, M.A.; Teixeira, M.M.; da Silva, T.A. Eosinophil depletion protects mice from tongue squamous cell carcinoma induced by 4-nitroquinoline-1-oxide. Histol. Histopathol. 2014, 29, 387-396. [PubMed]

198. Sakkal, S.; Miller, S.; Apostolopoulos, V.; Nurgali, K. Eosinophils in Cancer: Favourable or Unfavourable? Curr. Med. Chem. 2016, 23, 650-666. [CrossRef]

199. Xing, Y.; Tian, Y.; Kurosawa, T.; Matsui, S.; Touma, M.; Yanai, T.; Wu, Q.; Sugimoto, K. CCL11-induced eosinophils inhibit the formation of blood vessels and cause tumor necrosis. Genes Cells 2016, 21, 624-638. [CrossRef]

200. Lan, Q.; Lai, W.; Zeng, Y.; Liu, L.; Li, S.; Jin, S.; Zhang, Y.; Luo, X.; Xu, H.; Lin, X.; et al. CCL26 Participates in the PRL-3-Induced Promotion of Colorectal Cancer Invasion by Stimulating Tumor-Associated Macrophage Infiltration. Mol. Cancer Ther 2018, 17, 276-289. [CrossRef]

201. Jöhrer, K.; Zelle-Rieser, C.; Perathoner, A.; Moser, P.; Hager, M.; Ramoner, R.; Gander, H.; Höltl, L.; Bartsch, G.; Greil, R.; et al. Up-regulation of functional chemokine receptor CCR3 in human renal cell carcinoma. Clin. Cancer Res. 2005, 11, 2459-2465. [CrossRef]

202. Zhu, F.; Liu, P.; Li, J.; Zhang, Y. Eotaxin-1 promotes prostate cancer cell invasion via activation of the CCR3-ERK pathway and upregulation of MMP-3 expression. Oncol. Rep. 2014, 31, 2049-2054. [CrossRef]

203. Tian, M.; Chen, L.; Ma, L.; Wang, D.; Shao, B.; Wu, J.; Wu, H.; Jin, Y. Expression and prognostic significance of CCL11/CCR3 in glioblastoma. Oncotarget 2016, 7, 32617-32627. [CrossRef]

204. Miyagaki, T.; Sugaya, M.; Murakami, T.; Asano, Y.; Tada, Y.; Kadono, T.; Okochi, H.; Tamaki, K.; Sato, S. CCL11-CCR3 interactions promote survival of anaplastic large cell lymphoma cells via ERK1/2 activation. Cancer Res. 2011, 71, 2056-2065. [CrossRef] [PubMed]

205. Salcedo, R.; Young, H.A.; Ponce, M.L.; Ward, J.M.; Kleinman, H.K.; Murphy, W.J.; Oppenheim, J.J. Eotaxin (CCL11) induces in vivo angiogenic responses by human CCR3+ endothelial cells. J. Immunol. 2001, 166, 7571-7578. [CrossRef]

206. Park, J.Y.; Kang, Y.W.; Choi, B.Y.; Yang, Y.C.; Cho, B.P.; Cho, W.G. CCL11 promotes angiogenic activity by activating the PI3K/Akt pathway in HUVECs. J. Recept. Signal. Transduct. Res. 2017, 37, 416-421. [CrossRef]

207. Jin, L.; Liu, W.R.; Tian, M.X.; Jiang, X.F.; Wang, H.; Zhou, P.Y.; Ding, Z.B.; Peng, Y.F.; Dai, Z.; Qiu, S.J.; et al. CCL24 contributes to HCC malignancy via RhoB- VEGFA-VEGFR2 angiogenesis pathway and indicates poor prognosis. Oncotarget 2017, 8, 5135-5148. [CrossRef]

208. Imai, T.; Baba, M.; Nishimura, M.; Kakizaki, M.; Takagi, S.; Yoshie, O. The T cell-directed CC chemokine TARC is a highly specific biological ligand for CC chemokine receptor 4. J. Biol. Chem. 1997, 272, 15036-15042. [CrossRef]

209. Imai, T.; Chantry, D.; Raport, C.J.; Wood, C.L.; Nishimura, M.; Godiska, R.; Yoshie, O.; Gray, P.W. Macrophage-derived chemokine is a functional ligand for the CC chemokine receptor 4. J. Biol. Chem. 1998, 273, 1764-1768. [CrossRef]

210. Yoshie, O.; Matsushima, K. CCR4 and its ligands: From bench to bedside. Int. Immunol. 2015, $27,11-20$. [CrossRef]

211. Okada, N.; Sasaki, A.; Niwa, M.; Okada, Y.; Hatanaka, Y.; Tani, Y.; Mizuguchi, H.; Nakagawa, S.; Fujita, T.; Yamamoto, A. Tumor suppressive efficacy through augmentation of tumor-infiltrating immune cells by intratumoral injection of chemokine-expressing adenoviral vector. Cancer Gene Ther. 2006, 13, 393-405. [CrossRef] 
212. Kanagawa, N.; Niwa, M.; Hatanaka, Y.; Tani, Y.; Nakagawa, S.; Fujita, T.; Yamamoto, A.; Okada, N. CC-chemokine ligand 17 gene therapy induces tumor regression through augmentation of tumor-infiltrating immune cells in a murine model of preexisting CT26 colon carcinoma. Int. J. Cancer 2007, 121, 2013-2022. [CrossRef]

213. Wågsäter, D.; Dienus, O.; Löfgren, S.; Hugander, A.; Dimberg, J. Quantification of the chemokines CCL17 and CCL22 in human colorectal adenocarcinomas. Mol. Med. Rep. 2008, 1, 211-217.

214. Tsujikawa, T.; Yaguchi, T.; Ohmura, G.; Ohta, S.; Kobayashi, A.; Kawamura, N.; Fujita, T.; Nakano, H.; Shimada, T.; Takahashi, T.; et al. Autocrine and paracrine loops between cancer cells and macrophages promote lymph node metastasis via CCR4/CCL22 in head and neck squamous cell carcinoma. Int. J. Cancer 2013, 132, 2755-2766. [CrossRef]

215. Tripathi, C.; Tewari, B.N.; Kanchan, R.K.; Baghel, K.S.; Nautiyal, N.; Shrivastava, R.; Kaur, H.; Bhatt, M.L.; Bhadauria, S. Macrophages are recruited to hypoxic tumor areas and acquire a pro-angiogenic M2-polarized phenotype via hypoxic cancer cell derived cytokines Oncostatin M and Eotaxin. Oncotarget 2014, 5, 5350-5368. [CrossRef]

216. Wertel, I.; Surówka, J.; Polak, G.; Barczyński, B.; Bednarek, W.; Jakubowicz-Gil, J.; Bojarska-Junak, A.; Kotarski, J. Macrophage-derived chemokine CCL22 and regulatory T cells in ovarian cancer patients. Tumour. Biol. 2015, 36, 4811-4817. [CrossRef]

217. Zhang, W.; Chen, L.; Ma, K.; Zhao, Y.; Liu, X.; Wang, Y.; Liu, M.; Liang, S.; Zhu, H.; Xu, N. Polarization of macrophages in the tumor microenvironment is influenced by EGFR signaling within colon cancer cells. Oncotarget 2016, 7, 75366-75378. [CrossRef]

218. Zhu, F.; Li, X.; Chen, S.; Zeng, Q.; Zhao, Y.; Luo, F. Tumor-associated macrophage or chemokine ligand CCL17 positively regulates the tumorigenesis of hepatocellular carcinoma. Med. Oncol. 2016, 33, 17. [CrossRef] [PubMed]

219. Kimura, S.; Nanbu, U.; Noguchi, H.; Harada, Y.; Kumamoto, K.; Sasaguri, Y.; Nakayama, T. Macrophage CCL22 expression in the tumor microenvironment and implications for survival in patients with squamous cell carcinoma of the tongue. J. Oral. Pathol. Med. 2019, 48, 677-685. [CrossRef]

220. Mishalian, I.; Bayuh, R.; Eruslanov, E.; Michaeli, J.; Levy, L.; Zolotarov, L.; Singhal, S.; Albelda, S.M.; Granot, Z.; Fridlender, Z.G. Neutrophils recruit regulatory T-cells into tumors via secretion of CCL17-a new mechanism of impaired antitumor immunity. Int. J. Cancer 2014, 135, 1178-1186. [CrossRef]

221. Omland, S.H.; Wettergren, E.E.; Mollerup, S.; Asplund, M.; Mourier, T.; Hansen, A.J.; Gniadecki, R. Cancer associated fibroblasts (CAFs) are activated in cutaneous basal cell carcinoma and in the peritumoural skin. BMC Cancer 2017, 17, 675. [CrossRef] [PubMed]

222. Mizukami, Y.; Kono, K.; Kawaguchi, Y.; Akaike, H.; Kamimura, K.; Sugai, H.; Fujii, H. CCL17 and CCL22 chemokines within tumor microenvironment are related to accumulation of Foxp3+ regulatory $\mathrm{T}$ cells in gastric cancer. Int. J. Cancer 2008, 122, 2286-2293. [CrossRef] [PubMed]

223. Qin, X.J.; Shi, H.Z.; Deng, J.M.; Liang, Q.L.; Jiang, J.; Ye, Z.J. CCL22 recruits CD4-positive CD25-positive regulatory $\mathrm{T}$ cells into malignant pleural effusion. Clin. Cancer Res. 2009, 15, 2231-2237. [CrossRef]

224. Maruyama, T.; Kono, K.; Izawa, S.; Mizukami, Y.; Kawaguchi, Y.; Mimura, K.; Watanabe, M.; Fujii, H. CCL17 and CCL22 chemokines within tumor microenvironment are related to infiltration of regulatory $\mathrm{T}$ cells in esophageal squamous cell carcinoma. Dis. Esophagus 2010, 23, 422-429. [CrossRef] [PubMed]

225. Liu, W.; Wei, X.; Li, L.; Wu, X.; Yan, J.; Yang, H.; Song, F. CCR4 mediated chemotaxis of regulatory T cells suppress the activation of T cells and NK cells via TGF- $\beta$ pathway in human non-small cell lung cancer. Biochem. Biophys. Res. Commun. 2017, 488, 196-203. [CrossRef]

226. Xie, F.; Liu, L.B.; Shang, W.Q.; Chang, K.K.; Meng, Y.H.; Mei, J.; Yu, J.J.; Li, D.J.; Li, M.Q. The infiltration and functional regulation of eosinophils induced by TSLP promote the proliferation of cervical cancer cell. Cancer Lett. 2015, 364, 106-117. [CrossRef]

227. Chen, D.; Jiang, R.; Mao, C.; Shi, L.; Wang, S.; Yu, L.; Hu, Q.; Dai, D.; Xu, H. Chemokine/chemokine receptor interactions contribute to the accumulation of Th17 cells in patients with esophageal squamous cell carcinoma. Hum. Immunol. 2012, 73, 1068-1072. [CrossRef]

228. Li, Y.Q.; Liu, F.F.; Zhang, X.M.; Guo, X.J.; Ren, M.J.; Fu, L. Tumor secretion of CCL22 activates intratumoral Treg infiltration and is independent prognostic predictor of breast cancer. PLOS ONE 2013, 8, e76379. [CrossRef] 
229. Nakanishi, T.; Imaizumi, K.; Hasegawa, Y.; Kawabe, T.; Hashimoto, N.; Okamoto, M.; Shimokata, K. Expression of macrophage-derived chemokine (MDC)/CCL22 in human lung cancer. Cancer Immunol. Immunother. 2006, 55, 1320-1329. [CrossRef]

230. Weide, B.; Allgaier, N.; Hector, A.; Forschner, A.; Leiter, U.; Eigentler, T.K.; Garbe, C.; Hartl, D. Increased CCL17 serum levels are associated with improved survival in advanced melanoma. Cancer Immunol. Immunother. 2015, 64, 1075-1082. [CrossRef]

231. Li, X.; Li, D.; Shi, Q.; Huang, X.; Ju, X. Umbilical cord blood-derived Helios-positive regulatory T cells promote angiogenesis in acute lymphoblastic leukemia in mice via CCL22 and the VEGFA-VEGFR2 pathway. Mol. Med. Rep. 2019, 19, 4195-4204. [CrossRef]

232. Wei, C.; Yang, C.; Wang, S.; Shi, D.; Zhang, C.; Lin, X.; Xiong, B. M2 macrophages confer resistance to 5-fluorouracil in colorectal cancer through the activation of CCL22/PI3K/AKT signaling. Oncol. Targets Ther. 2019, 12, 3051-3063. [CrossRef]

233. Liu, L.B.; Xie, F.; Chang, K.K.; Shang, W.Q.; Meng, Y.H.; Yu, J.J.; Li, H.; Sun, Q.; Yuan, M.M.; Jin, L.P.; et al. Chemokine CCL17 induced by hypoxia promotes the proliferation of cervical cancer cell. Am. J. Cancer Res. 2015, 5, 3072-3084.

234. Al-haidari, A.A.; Syk, I.; Jirström, K.; Thorlacius, H. CCR4 mediates CCL17 (TARC)-induced migration of human colon cancer cells via RhoA/Rho-kinase signaling. Int. J. Colorectal Dis. 2013, 28, 1479-1487. [CrossRef]

235. Cao, L.; Hu, X.; Zhang, J.; Huang, G.; Zhang, Y. The role of the CCL22-CCR4 axis in the metastasis of gastric cancer cells into omental milky spots. J. Transl. Med. 2014, 12, 267. [CrossRef] [PubMed]

236. Nakamura, E.S.; Koizumi, K.; Kobayashi, M.; Saitoh, Y.; Arita, Y.; Nakayama, T.; Sakurai, H.; Yoshie, O.; Saiki, I. RANKL-induced CCL22/macrophage-derived chemokine produced from osteoclasts potentially promotes the bone metastasis of lung cancer expressing its receptor CCR4. Clin. Exp. Metastasis 2006, 23, 9-18. [CrossRef]

237. Klein, A.; Sagi-Assif, O.; Meshel, T.; Telerman, A.; Izraely, S.; Ben-Menachem, S.; Bayry, J.; Marzese, D.M.; Ohe, S.; Hoon, D.S.B.; et al. CCR4 is a determinant of melanoma brain metastasis. Oncotarget 2017, 8, 31079-31091. [CrossRef]

238. Olkhanud, P.B.; Baatar, D.; Bodogai, M.; Hakim, F.; Gress, R.; Anderson, R.L.; Deng, J.; Xu, M.; Briest, S.; Biragyn, A. Breast cancer lung metastasis requires expression of chemokine receptor CCR4 and regulatory $\mathrm{T}$ cells. Cancer Res. 2009, 69, 5996-6004. [CrossRef]

239. Fagerberg, L.; Hallström, B.M.; Oksvold, P.; Kampf, C.; Djureinovic, D.; Odeberg, J.; Habuka, M.; Tahmasebpoor, S.; Danielsson, A.; Edlund, K.; et al. Analysis of the human tissue-specific expression by genome-wide integration of transcriptomics and antibody-based proteomics. Mol. Cell Proteomics 2014, 13, 397-406. [CrossRef]

240. Arneth, B. Tumor Microenvironment. Medicina (Kaunas) 2019, 56, 15. [CrossRef]

241. Lapteva, N.; Aldrich, M.; Weksberg, D.; Rollins, L.; Goltsova, T.; Chen, S.Y.; Huang, X.F. Targeting the intratumoral dendritic cells by the oncolytic adenoviral vaccine expressing RANTES elicits potent antitumor immunity. J. Immunother. 2009, 32, 145-156. [CrossRef]

242. Igoucheva, O.; Grazzini, M.; Pidich, A.; Kemp, D.M.; Larijani, M.; Farber, M.; Lorton, J.; Rodeck, U.; Alexeev, V. Immunotargeting and eradication of orthotopic melanoma using a chemokine-enhanced DNA vaccine. Gene Ther. 2013, 20, 939-948. [CrossRef]

243. Li, J.; Liu, H.; Li, L.; Wu, H.; Wang, C.; Yan, Z.; Wang, Y.; Su, C.; Jin, H.; Zhou, F.; et al. The combination of an oxygen-dependent degradation domain-regulated adenovirus expressing the chemokine RANTES/CCL5 and NK-92 cells exerts enhanced antitumor activity in hepatocellular carcinoma. Oncol. Rep. 2013, 29, 895-902. [CrossRef] [PubMed]

244. Lai, J.Z.; Zhu, Y.Y.; Ruan, M.; Chen, L.; Zhang, Q.Y. Local Irradiation Sensitized Tumors to Adoptive T Cell Therapy via Enhancing the Cross-Priming, Homing, and Cytotoxicity of Antigen-Specific CD8 T Cells. Front. Immunol. 2019, 10, 2857. [CrossRef] [PubMed]

245. Guiducci, C.; Vicari, A.P.; Sangaletti, S.; Trinchieri, G.; Colombo, M.P. Redirecting in vivo elicited tumor infiltrating macrophages and dendritic cells towards tumor rejection. Cancer Res. 2005, 65, 3437-3446. [CrossRef] 
246. Mauri, G.; Chiodoni, C.; Parenza, M.; Arioli, I.; Tripodo, C.; Colombo, M.P. Ultrasound-guided intra-tumor injection of combined immunotherapy cures mice from orthotopic prostate cancer. Cancer Immunol. Immunother. 2013, 62, 1811-1819. [CrossRef]

247. Kitamura, T.; Fujishita, T.; Loetscher, P.; Revesz, L.; Hashida, H.; Kizaka-Kondoh, S.; Aoki, M.; Taketo, M.M. Inactivation of chemokine (C-C motif) receptor 1 (CCR1) suppresses colon cancer liver metastasis by blocking accumulation of immature myeloid cells in a mouse model. Proc. Natl. Acad. Sci. USA 2010, 107, 13063-13068. [CrossRef] [PubMed]

248. Fang, W.B.; Yao, M.; Brummer, G.; Acevedo, D.; Alhakamy, N.; Berkland, C.; Cheng, N. Targeted gene silencing of CCL2 inhibits triple negative breast cancer progression by blocking cancer stem cell renewal and M2 macrophage recruitment. Oncotarget 2016, 7, 49349-49367. [CrossRef]

249. Shen, S.; Zhang, Y.; Chen, K.G.; Luo, Y.L.; Wang, J. Cationic Polymeric Nanoparticle Delivering CCR2 siRNA to Inflammatory Monocytes for Tumor Microenvironment Modification and Cancer Therapy. Mol. Pharm. 2018, 15, 3642-3653. [CrossRef] [PubMed]

250. Zhu, X.; Fujita, M.; Snyder, L.A.; Okada, H. Systemic delivery of neutralizing antibody targeting CCL2 for glioma therapy. J. Neurooncol. 2011, 104, 83-92. [CrossRef]

251. Cho, H.R.; Kumari, N.; Thi, V.H.; Kim, H.; Park, C.K.; Choi, S.H. Increased Antiangiogenic Effect by Blocking CCL2-dependent Macrophages in a Rodent Glioblastoma Model: Correlation Study with Dynamic Susceptibility Contrast Perfusion MRI. Sci. Rep. 2019, 9, 11085. [CrossRef] [PubMed]

252. Flores-Toro, J.A.; Luo, D.; Gopinath, A.; Sarkisian, M.R.; Campbell, J.J.; Charo, I.F.; Singh, R.; Schall, T.J.; Datta, M.; Jain, R.K.; et al. CCR2 inhibition reduces tumor myeloid cells and unmasks a checkpoint inhibitor effect to slow progression of resistant murine gliomas. Proc. Natl. Acad. Sci. USA 2020, 117, 1129-1138. [CrossRef] [PubMed]

253. Teng, K.Y.; Han, J.; Zhang, X.; Hsu, S.H.; He, S.; Wani, N.A.; Barajas, J.M.; Snyder, L.A.; Frankel, W.L.; Caligiuri, M.A.; et al. Blocking the CCL2-CCR2 Axis Using CCL2-Neutralizing Antibody Is an Effective Therapy for Hepatocellular Cancer in a Mouse Model. Mol. Cancer Ther. 2017, 16, 312-322. [CrossRef]

254. Trac, N.; Chen, L.Y.; Zhang, A.; Liao, C.P.; Poon, C.; Wang, J.; Ando, Y.; Joo, J.; Garri, C.; Shen, K.; et al. CCR2-targeted micelles for anti-cancer peptide delivery and immune stimulation. J. Control. Release 2020. [CrossRef]

255. Sandhu, S.K.; Papadopoulos, K.; Fong, P.C.; Patnaik, A.; Messiou, C.; Olmos, D.; Wang, G.; Tromp, B.J.; Puchalski, T.A.; Balkwill, F; et al. A first-in-human, first-in-class, phase I study of carlumab (CNTO 888), a human monoclonal antibody against CC-chemokine ligand 2 in patients with solid tumors. Cancer Chemother. Pharmacol. 2013, 71, 1041-1050. [CrossRef]

256. Moisan, F.; Francisco, E.B.; Brozovic, A.; Duran, G.E.; Wang, Y.C.; Chaturvedi, S.; Seetharam, S.; Snyder, L.A.; Doshi, P.; Sikic, B.I. Enhancement of paclitaxel and carboplatin therapies by CCL2 blockade in ovarian cancers. Mol. Oncol. 2014, 8, 1231-1239. [CrossRef]

257. Qian, D.Z.; Rademacher, B.L.; Pittsenbarger, J.; Huang, C.Y.; Myrthue, A.; Higano, C.S.; Garzotto, M.; Nelson, P.S.; Beer, T.M. CCL2 is induced by chemotherapy and protects prostate cancer cells from docetaxel-induced cytotoxicity. Prostate 2010, 70, 433-442. [CrossRef]

258. Connolly, K.A.; Belt, B.A.; Figueroa, N.M.; Murthy, A.; Patel, A.; Kim, M.; Lord, E.M.; Linehan, D.C.; Gerber, S.A. Increasing the efficacy of radiotherapy by modulating the CCR2/CCR5 chemokine axes. Oncotarget 2016, 7, 86522-86535. [CrossRef]

259. Kalbasi, A.; Komar, C.; Tooker, G.M.; Liu, M.; Lee, J.W.; Gladney, W.L.; Ben-Josef, E.; Beatty, G.L. Tumor-Derived CCL2 Mediates Resistance to Radiotherapy in Pancreatic Ductal Adenocarcinoma. Clin. Cancer Res. 2017, 23, 137-148. [CrossRef]

260. Guo, S.S.; Liu, R.; Wen, Y.F.; Liu, L.T.; Yuan, L.; Li, Y.X.; Li, Y.; Hao, W.W.; Peng, J.Y.; Chen, D.N.; et al. Endogenous production of $\mathrm{C}-\mathrm{C}$ motif chemokine ligand 2 by nasopharyngeal carcinoma cells drives radioresistance-associated metastasis. Cancer Lett. 2020, 468, 27-40. [CrossRef] [PubMed]

261. Yan, C.; Luo, L.; Urata, Y.; Goto, S.; Li, T.S. Nicaraven reduces cancer metastasis to irradiated lungs by decreasing CCL8 and macrophage recruitment. Cancer Lett. 2018, 418, 204-210. [CrossRef]

262. Belarbi, K.; Jopson, T.; Arellano, C.; Fike, J.R.; Rosi, S. CCR2 deficiency prevents neuronal dysfunction and cognitive impairments induced by cranial irradiation. Cancer Res. 2013, 73, 1201-1210. [CrossRef] 
263. Lee, S.W.; Haditsch, U.; Cord, B.J.; Guzman, R.; Kim, S.J.; Boettcher, C.; Priller, J.; Ormerod, B.K.; Palmer, T.D. Absence of CCL2 is sufficient to restore hippocampal neurogenesis following cranial irradiation. Brain Behav. Immun. 2013, 30, 33-44. [CrossRef]

264. Wiesemann, A.; Ketteler, J.; Slama, A.; Wirsdörfer, F.; Hager, T.; Röck, K.; Engel, D.R.; Fischer, J.W.; Aigner, C.; Jendrossek, V.; et al. Inhibition of Radiation-Induced Ccl2 Signaling Protects Lungs from Vascular Dysfunction and Endothelial Cell Loss. Antioxid. Redox Signal. 2019, 30, 213-231. [CrossRef]

265. Fridlender, Z.G.; Buchlis, G.; Kapoor, V.; Cheng, G.; Sun, J.; Singhal, S.; Crisanti, M.C.; Wang, L.C.; Heitjan, D.; Snyder, L.A.; et al. CCL2 blockade augments cancer immunotherapy. Cancer Res. 2010, 70, 109-118. [CrossRef]

266. Fridlender, Z.G.; Kapoor, V.; Buchlis, G.; Cheng, G.; Sun, J.; Wang, L.C.; Singhal, S.; Snyder, L.A.; Albelda, S.M. Monocyte chemoattractant protein-1 blockade inhibits lung cancer tumor growth by altering macrophage phenotype and activating CD8+ cells. Am. J. Respir. Cell Mol. Biol. 2011, 44, 230-237. [CrossRef]

267. Cheadle, E.J.; Riyad, K.; Subar, D.; Rothwell, D.G.; Ashton, G.; Batha, H.; Sherlock, D.J.; Hawkins, R.E.; Gilham, D.E. Eotaxin-2 and colorectal cancer: A potential target for immune therapy. Clin. Cancer Res. 2007, 13, 5719-5728. [CrossRef] [PubMed]

268. Maeda, S.; Murakami, K.; Inoue, A.; Yonezawa, T.; Matsuki, N. CCR4 Blockade Depletes Regulatory T Cells and Prolongs Survival in a Canine Model of Bladder Cancer. Cancer Immunol. Res. 2019, 7, 1175-1187. [CrossRef]

269. Berlato, C.; Khan, M.N.; Schioppa, T.; Thompson, R.; Maniati, E.; Montfort, A.; Jangani, M.; Canosa, M.; Kulbe, H.; Hagemann, U.B.; et al. A CCR4 antagonist reverses the tumor-promoting microenvironment of renal cancer. J. Clin. Invest. 2017, 127, 801-813. [CrossRef]

270. Rapp, M.; Grassmann, S.; Chaloupka, M.; Layritz, P.; Kruger, S.; Ormanns, S.; Rataj, F.; Janssen, K.P.; Endres, S.; Anz, D.; et al. C-C chemokine receptor type-4 transduction of T cells enhances interaction with dendritic cells, tumor infiltration and therapeutic efficacy of adoptive T cell transfer. Oncoimmunology 2015, 5, e1105428. [CrossRef]

271. Guo, J.; Wang, B.; Zhang, M.; Chen, T.; Yu, Y.; Regulier, E.; Homann, H.E.; Qin, Z.; Ju, D.W.; Cao, X. Macrophage-derived chemokine gene transfer results in tumor regression in murine lung carcinoma model through efficient induction of antitumor immunity. Gene Ther. 2002, 9, 793-803. [CrossRef]

272. Okada, N.; Gao, J.Q.; Sasaki, A.; Niwa, M.; Okada, Y.; Nakayama, T.; Yoshie, O.; Mizuguchi, H.; Hayakawa, T.; Fujita, T.; et al. Anti-tumor activity of chemokine is affected by both kinds of tumors and the activation state of the host's immune system: Implications for chemokine-based cancer immunotherapy. Biochem. Biophys. Res. Commun. 2004, 317, 68-76. [CrossRef]

273. Cohen, E.E.W.; Pishvaian, M.J.; Shepard, D.R.; Wang, D.; Weiss, J.; Johnson, M.L.; Chung, C.H.; Chen, Y.; Huang, B.; Davis, C.B.; et al. A phase Ib study of utomilumab (PF-05082566) in combination with mogamulizumab in patients with advanced solid tumors. J. Immunother. Cancer 2019, 7, 342. [CrossRef]

274. Doi, T.; Muro, K.; Ishii, H.; Kato, T.; Tsushima, T.; Takenoyama, M.; Oizumi, S.; Gemmoto, K.; Suna, H.; Enokitani, K.; et al. A Phase I Study of the Anti-CC Chemokine Receptor 4 Antibody, Mogamulizumab, in Combination with Nivolumab in Patients with Advanced or Metastatic Solid Tumors. Clin. Cancer Res. 2019, 25, 6614-6622. [CrossRef] [PubMed]

275. Yamamoto, K.; Utsunomiya, A.; Tobinai, K.; Tsukasaki, K.; Uike, N.; Uozumi, K.; Yamaguchi, K.; Yamada, Y.; Hanada, S.; Tamura, K.; et al. Phase I study of KW-0761, a defucosylated humanized anti-CCR4 antibody, in relapsed patients with adult T-cell leukemia-lymphoma and peripheral T-cell lymphoma. J. Clin. Oncol. 2010, 28, 1591-1598. [CrossRef]

276. Ishida, T.; Utsunomiya, A.; Jo, T.; Yamamoto, K.; Kato, K.; Yoshida, S.; Takemoto, S.; Suzushima, H.; Kobayashi, Y.; Imaizumi, Y.; et al. Mogamulizumab for relapsed adult T-cell leukemia-lymphoma: Updated follow-up analysis of phase I and II studies. Cancer Sci. 2017, 108, 2022-2029. [CrossRef] [PubMed]

277. Ogura, M.; Ishida, T.; Hatake, K.; Taniwaki, M.; Ando, K.; Tobinai, K.; Fujimoto, K.; Yamamoto, K.; Miyamoto, T.; Uike, N.; et al. Multicenter phase II study of mogamulizumab (KW-0761), a defucosylated anti-cc chemokine receptor 4 antibody, in patients with relapsed peripheral T-cell lymphoma and cutaneous T-cell lymphoma. J. Clin. Oncol. 2014, 32, 1157-1163. [CrossRef] 
278. Duvic, M.; Pinter-Brown, L.C.; Foss, F.M.; Sokol, L.; Jorgensen, J.L.; Challagundla, P.; Dwyer, K.M.; Zhang, X.; Kurman, M.R.; Ballerini, R.; et al. Phase 1/2 study of mogamulizumab, a defucosylated anti-CCR4 antibody, in previously treated patients with cutaneous T-cell lymphoma. Blood 2015, 125, 1883-1889. [CrossRef] [PubMed]

279. Kanazawa, T.; Hiramatsu, Y.; Iwata, S.; Siddiquey, M.; Sato, Y.; Suzuki, M.; Ito, Y.; Goshima, F.; Murata, T.; Kimura, H. Anti-CCR4 monoclonal antibody mogamulizumab for the treatment of EBV-associated T- and NK-cell lymphoproliferative diseases. Clin. Cancer Res. 2014, 20, 5075-5084. [CrossRef]

Publisher's Note: MDPI stays neutral with regard to jurisdictional claims in published maps and institutional affiliations.

(C) 2020 by the authors. Licensee MDPI, Basel, Switzerland. This article is an open access article distributed under the terms and conditions of the Creative Commons Attribution (CC BY) license (http://creativecommons.org/licenses/by/4.0/). 